\title{
SHOULD UNNECESSARY HARMFUL NONTHERAPEUTIC COSMETIC SURGERY BE CRIMINALIZED?
}

\author{
Dennis J. Baker*
}

In this article, it is argued that an application of the harm principle to many forms of nontherapeutic cosmetic surgery shows that these procedures are a form of physical harm, not a form of medicine, and therefore ought to be criminalized. Not only does the harm principle support the case for criminalization, but so too do the relevant precedents. This article focuses on the general moral justifications (wrongful harm to others) for criminalizing unnecessary harmful cosmetic surgery, but legal doctrine is also invoked to demonstrate that there is a legal justification for criminalization. The famous English case of R. v. Brown ${ }^{1}$ will be discussed to outline the core legal case for criminalization. This article does not aim to provide a comparative study of the U.S. and English authorities, but rather aims to make theoretical arguments for criminalization, and thus, works from the legal premise that in most states the U.S. courts have taken a similar position to that taken in the seminal English House of Lords decision in R. v. Brown.

Keywords: criminal law, cosmetic surgery, criminalization, minors, medicine

\section{INTRODUCTION}

The medical profession has medicalized a range of harmful procedures that provide no long-term benefit for their (putative patients) victims. It will be argued that a statutory criminal offense is required to protect adults from

* Dennis J. Baker (M.Phil. Ph.D., Jesus College, University of Cambridge), Reader in English Law, School of Law, King's College London.

I. [1994] I A.C. 2 I2.

New Criminal Law Review, Vol. I7, Number 4, pps 587-630. ISSN 1933-4192, electronic ISSN 1933-4206. (C) 2014 by the Regents of the University of California. All rights reserved. Please direct all requests for permission to photocopy or reproduce article content through the University of California Press's Rights and Permissions website, http://www.ucpressjournals.com/reprintInfo.asp. DOI: IO.I525/nclr.20I4.I7.4.587. 
unnecessary harmful nontherapeutic cosmetic surgery. Furthermore, it is argued that if the consent of adults cannot annul the wrongness of unnecessary harmful nontherapeutic cosmetic surgery, ${ }^{2}$ a fortiori a minor's (for present purposes, a person aged under I8) consent cannot annul the wrongness of such surgery. The general focus is on wrongful harm to others as justification for criminalizing this sort of surgery. In the case of minors additional factors lend weight to the case for criminalization. Arguably, the reduced capacity and vulnerability of minors adds weight to the case for protecting all minors from such surgery.

The core justification for criminalizing this sort of surgery for minors is the same as for criminalizing it for adults: The core justification in both cases is that this sort of surgery involves wrongful harm to others. A minor's immaturity and vulnerability are only additional factors that balance the scales further in favor of criminalization. At the very least there should be a special offense to protect minors, because those aged 17 and under are particularly vulnerable to peer and media pressure. Coupled with this, even a mature minor lacks the maturity of an experienced adult.

Harmful cosmetic surgery that is nontherapeutic and otherwise unnecessary cannot be justified as lawful under the prevailing U.S. and English authorities ${ }^{3}$ because the precedents deny consent as a defense to wanton violence that results in bodily harm, unless it comes within one of the exceptions where the courts have recognized consent as a defense. In $R$. v. Brown, ${ }^{4}$ the House of Lords held that consent does not provide a defense to those who inflict actual or grievous (serious) bodily harm upon others unless the harm results from (I) reasonable surgical operations, (2) reasonable adornment procedures, ${ }^{5}$ (3) properly conducted sports games, (4) dangerous feats and exhibitions, (5) reasonable horseplay. ${ }^{6}$

2. R. v. Brown [1994] I A.C. 212. The U.S. courts have taken a similar approach. See Bass v. State (196I) I20 SE 2d 580; People v. Kevorkian (200I) 248 Mich. App. 373; Commonwealth v. Appleby (1980) 380 Mass. 296; People v. Samuels (1967) 250 Cal. App. 2d 50I.

3. R. v. Brown [1994] I A.C. $2 \mathrm{I} 2$ is a case that has attracted a lot of attention from scholars on both sides of the Atlantic. This year alone it has been discussed in Margo Kaplan, Sex-Positive Law, (2014) 89 N.Y.U. L. Rev. 89; Jack Anderson, The Right to a Fair Fight: Sporting Lessons on Consensual Harm, (2014) I7 New Crim. L. Rev. 55; Elaine Craig, Capacity to Consent to Sexual Risk, (20I4) I7 New Crim. L. Rev. Io3; Edward Stein, Immutability and Innateness Arguments About Lesbian, Gay, and Bisexual Rights, (2014) 89 CHI.-Kent L. Rev. 597.

4. [1994] I A.C. $2 \mathrm{I2}$.

5. R. v. Wilson [1997] Q.B. 47.

6. R. v. Jones (1986) 83 Cr. App. R. 375. 
The consenting victims of nontherapeutic harmful cosmetic surgery may not feel wronged because they consent, but they are wronged and harmed. They are wronged and harmed because the surgeon uses them as a means to an end, that is, as an object for making money. The issue is not about criminalizing the consenter (the putative patient); instead, it is about criminalizing the harm-doer, the surgeon. A criminal offense would not limit the self-harmer's freedom to self-harm ${ }^{7}$; her freedom would be limited only to the extent that others will be deterred from harming her.

In $R . v$. Brown a group of sadomasochists voluntarily and enthusiastically committed acts of violence against each other, because they achieved sexual gratification from being subjected to violence and pain. The appellants were arraigned on various counts under $\S \S 20$ and 47 of the Offenses Against the Person Act I86I (U.K.) for aggravated assault, for inflicting wounds and actual bodily harm on the genital and other areas of the bodies of each other. Space prohibits consideration of all the $R$. v. Brown exceptions where consent provides a defense, so the discussion in this article will be only on the reasonable surgery exception.

It will be agued that the decision of the English House of Lords in $R . v$. Brown only provides an exception for genuine medicine. Nontherapeutic cosmetic surgery resulting in minor injury and no long-term damage might come within the reasonable adornment exception, but unnecessary nontherapeutic surgery that results in serious longer-term harm does not come within the adornment or medical exceptions.

\section{DIRECT HARM}

Cosmetic surgery is a growth industry. ${ }^{8}$ The remote harm to society is that scarce medical resources are used for nonlegitimate and unnecessary

7. Self-mutilation might result from a psychiatric disorder, but it might also be culturally contingent. See the examples given in Armando R. FaVAzZa, bodies under Siege: SelfMUTILATION IN CULTURE AND PSYCHIATRY (2nd ed. I996).

8. Statistics from the American Society of Plastic Surgeons show that in the United States in 2012, I4.6 million cosmetic plastic surgery procedures were performed. See http://www. plasticsurgery.org/news/press-release-archives/2013/I4-million-cosmetic-plastic-surgeryprocedures-performed-in-20I2.html. Similarly, in the United Kingdom, it has been reported that 50,122 cosmetic procedures were performed in 20I3, which is a $17 \%$ increase on the previous year. See James Gallagher, Plastic Surgery "Booming" in the UK, (Bв त News, Feb. 3, 20I4). 
surgical procedures when they could be used elsewhere to cure people who are ill. ${ }^{9}$ It is a market that results in remote harms, because it uses up valuable medical resources that are needed elsewhere. I have argued elsewhere that doing remote harm rarely provides a basis for direct criminalization. ${ }^{10}$ Who is the remote harm-doer? Is it the putative patient who supplies the demand that is the cosmetic surgery industry's raison d'etre? What motivates the putative patient to seek such procedures? Arguably the core impetus for the market is the social and cultural environment we live in where the masses are obsessed with celebrities, youth, and beauty. ${ }^{11}$ Celebrity, youth, and beauty are held up as values that outweigh skill and merit in our society.

Nonetheless, the direct harm-doer is the surgeon who chooses to use her skills to make money from providing nontherapeutic harmful surgery instead of therapeutic surgery. Remote harms should be dealt with via noncriminal state responses. In this article, the focus is on the direct harm-doer. The surgeon directly harms the putative patient by providing her with unnecessary harmful nontherapeutic cosmetic surgery.

Medical professionals have a moral and legal duty to act in the best interests of their patients and to take reasonable care when treating

9. For example, in Britain it has been observed: "The demand for labial reduction surgery is constantly increasing. Healthcare funds are becoming limited and in the current financial and National Health Service atmosphere labiaplasty might be seen as luxury rather than a necessity. It could be argued it places an unnecessary burden on the already scarce healthcare funds. In many units this procedure is no longer provided by the NHS. The vast majority of women seeking surgery have normal labia. More than $50 \%$ of these women do so because they perceive their labia enlarged and wish to make them smaller to improve appearance." See Elisabeth J. Adams et al., Labiaplasty, 22(2) Obstetrics, Gynecology \& Reproductive Medicine 50 at 52 (20I2).

Io. See Dennis J. Baker, The Moral Limits of Criminalizing Remote Harms, Io(3) New Crim. L. Rev. 370 (2007); Dennis J. Baker, The Right Not to Be Criminalized: Demarcating Criminal Law's Authority, at ch. 4 (20ii).

II. On socialization and consumer identity choices, see Shay Sayre, Cosmetic Surgery and Self-Transformation, in The Routledge Companion to Identity and Consumption I59 (Ayalla A. Ruvio \& Russell W. Belk eds., 20I2); R. Taylor et. al., Acceptance of Cosmetic Surgery and Celebrity Worship: Evidence of Associations Among Female Undergraduates, 47(8) Personality \& Individual Differences 869 (2009); J. Maltby \& L. Day, Celebrity Worship and Incidence of Elective Cosmetic Surgery: Evidence of a Link Among Young Adults, 49(5) J. Adolescent Health 483 (20II). 
patients. ${ }^{12}$ They have a duty to exercise such reasonable care, as the patient's known medical condition requires. They have long been allowed to risk causing serious harm to a patient where, on the balance of interests, the risky medical procedure was the lesser of two evils. ${ }^{13}$ A surgeon can take risks, but the risks must be calculated and aimed at enhancing the patient's health interests. ${ }^{14}$ Medical procedures carried out in a grossly negligent manner, in some circumstances, will result in criminal liability. ${ }^{15}$ Seven hundred years ago, Horne wrote:

Again ye are to distinguish of other men-slayers; as of physicians, jurors, justices, witnesses, of ideots, madmen and fugitives; for physicians and chirurgions are skilful in their faculties, and probably do lawful cures having good consciences, so as nothing faileth to the patient which to their art belongeth; if their patients die, they are not thereby men-slayers or mayhemors; but if they take upon them a cure, and have no knowledge or skill therein; or if they have knowledge, if nevertheless they neglect the cure, or minister that which is cold for hot, or hot for cold, or take little care thereof, or neglect due diligence therein, and especially in burning, and cutting off of members which they are forbidden to do but at the peril of their patient; if

I2. That does not mean that doctors have to act in the patient's best interests, if she has full capacity and refuses a medically necessary amputation and so on. See Heart of England NHS Foundation Trust v. JB [20I4] EWHC 342 (COP); Schreiber by Krueger v. Physicians Ins. Co. of Wisconsin (1998) 2I7 Wis. 2d 94. Cf. Great Western Hospitals NHS Foundation Trust v. AA [20I4] EWHC I32 (Fam); Woolley v. Henderson, (1980) 4I8 A.2d II23. On the duties doctors owe patients, and the scope of the duty, see R. v. Adomako [1995] I A.C. I7I; see also the insightful U.S. authorities such as Simpson v. Davis (1976) 219 Kan. 584 at 587; Stevenson v. Yates (19I) 208 S.W. 820; Marshall v. Klebanov (2006) I88 902 A.2d 873; White v. Harris (20II) 36 A.3d 203; Ward v. U.S. (1988) 838 F.2d I82; Meena v. Wilburn (I992) 603 So. $2 \mathrm{~d} 866$.

I3. R. v. Cox (1992) I2 B.M.L.R. 38.

I4. See the discussion in Dennis J. Baker, Glanville Williams: Textbook of Criminal Law, ch.24 (20I2). See also In Re A (Children) (Conjoined Twins: Surgical Separation) [200I] 2 W.L.R. 480. In State v. Beck (I833) I Hill (SC) 363, Harper, J. said: "If, according to the prescription of the physician in the Arabian Nights, a physician should beat his patient with a mallet, for the bona fide purpose of restoring his health, ... it would be no battery." Cf. Alec Walen, Doing, Allowing, and Disabling: Some Principles Governing Deontological Restrictions, 8o(2) PHIL. STUd. I83 (1995).

15. Generally, English criminal law does not contain offenses of negligence. The core exception is gross negligence manslaughter. See R. v. Adomako [1995] I A.C. I7I. Cf. the position in some U.S. jurisdictions, Tarpeh v. U.S. (2013) 62 A.3d I266; Sanchez v. PereiraCastillo (2009) 590 F.3d 3I. 
their patients die, or lose their members, in such cases they are men-slayers or mayhemors. ${ }^{16}$

Interestingly, Horne states that surgeons should not wantonly remove limbs because that is forbidden. Horne not only refers to manslaughter, but also to the old common law offense of maiming. In $R . v$. Wright ${ }^{17}$ it was held that: "[A] person who ... maims himself, or procures another to maim him, that he may have more color to beg; or disables himself to prevent being pressed for a soldier is subject to fine and imprisonment at common law; and so is the party by whom it was effected at the other's desire." Horne said, "Mayhem is the want of member, or the enfeebling of it by breaking, or cutting the bones of a man, whereby he is less able to combat."18

In State $v$. Bass, ${ }^{19}$ Bryson told Bass (a physician) that he was going to cut off his fingers to try to obtain insurance money. The physician refused to amputate Bryson's fingers, but accepted payment to inject his fingers with procaine so that he would not feel pain when the attempt was made to cut off his fingers. Bass also gave Bryson a rubber tourniquet to stop the likely bleeding and showed him how to apply and use it. Thereafter, a third party, Tryson, at Bryson's request, used an electric saw to cut off four fingers. Moore, J., took the view that Bass was criminally liable as an accessory to the maiming because he assisted the perpetrator and instigator of the maiming. It also was held that consent provided no defense, because of the level of harm inflicted. Moore, J., was not only concerned about the ulterior attempted fraud that Bass knowingly facilitated, but also about the

I6. Andrew Horne, The Mirrour of Justices at 206 (W. H. of Gray's Inn, trans., 1903). The Mirrour of Justices was first published in 1328 in old French: the original manuscript is in the Parker Library, Corpus Christi College, Cambridge (manuscript identifier CCCC MS 258)).

17. This is the text of the case as reported in Edward Hyde East, A Treatise of the Pleas of the Crown, Vol. I at 396 (I803).

I8. Horne, supra note I6, at 45. Cf. R. v. Tickner (I778) I Leach I87; R. v. Lee (I763) I Leach 5I; R. v. Mills (I783) I Leach 259; R. v. Hunt (I825) I Mood. C.C. 93. "Note, the life and members of every subject are under the safeguard and protection of the king to the end that they may serve the king and their countrie, when occasion shall be offered. ... Nay, the lord of the villiene, for the cause aforesaid, cannot mayhem the villiene, but the king shall punish him for mayheming of his subject (for that hereby he hath disabled him to do the king service) by fine, ransome, and imprisonment, until the fine and ransome be paid." SIR Edward Coke, The First Part of the Institutes of the Laws of England at i27a, 288a (1670).

19. (196I) I20 SE 2d 580. 
harm posed to society where a person uses another to disable him- or herself.

It was once a crime to commit suicide or self-maim, but that is no longer the law in England and Wales nor in most states in the United States. The Offenses Against the Person Act I86I (U.K) replaced the old offense of maiming and did not replace it with any offense that criminalizes self-harm. Self-harm requires a medical response, not a criminal law response. The medical cost to the state is a remote harm and thus should not be used as a basis for criminalization. In cases where the self-harm is perpetrated to facilitate some ulterior crime such as insurance fraud, the appropriate criminal law response is to convict the self-harmer of the ulterior crime alone (i.e., fraud).

Furthermore, a person should not be liable as an accessory for allowing another to harm her. ${ }^{20}$ If the surgeon in State $v$. Bass ${ }^{21}$ had used proper medical procedures to remove the consenter's fingers to help the consenter to commit fraud, there would have been no bar (assuming he had the requisite mens rea for complicity) to convicting him as accessory to fraud. What's more, such a surgeon should be convictable of an aggravated assault, because he deliberately inflicts serious bodily harm upon another without lawful justification. The fact that other has consented to the harm does not provide a defense, because the wrongness of wantonly inflicting serious harm upon another human being is not annulled by the victim's consent. ${ }^{22}$

The harm in a case like State v. Bass is not an inherent aspect or side effect of genuine therapeutic surgery, nor is it reasonable adornment, so consent should provide no defense. Even if a surgeon uses the same safe medical procedures (i.e., performs the surgery lege artis: according to the rules of medicine) that he would have used if the fingers had needed to be removed for a genuine medical reason such as to stop gangrene from spreading, ${ }^{23}$ the patient's consent is no defense when the surgery is merely

20. See Dennis J. Baker, Reinterpreting Complicity, Ch. 3 (20i5, forthcoming).

2I. (I96I) I2O SE 2d 580.

22. BAKER, supra note I4, at Ch. 23.

23. In a time when self-murder was still a crime, Hale wrote: "If A. with an intent to prevent a gangrene beginning in his hand doth without any advice cut off his hand, by which he dies, he is not thereby felo de se, for tho it was a voluntary act, yet it was not with an intent to kill himself." Matthew Hale, The History of the Pleas of the Crown at $4 \mathrm{I} 2$ (I736). 
aimed at facilitating insurance fraud. Such a surgeon does not act for a medical purpose, but to facilitate fraud. This sort of wanton surgery is not lawfully justifiable because the surgery is therapeutically unnecessary and results in serious injury. Such a surgeon is not relying on the defense of medical necessity or necessity more generally, but simply on the consent of the patient. ${ }^{24}$ The latter is not enough to annul the wrongness of amputating healthy fingers to facilitate insurance fraud. Instead, the surgeon causes the consenting patient unnecessary serious bodily harm for a nontherapeutic reason.

The common themes in the case law are simply that a putative medical procedure resulting in serious injury has to in fact involve genuine therapeutic medicine (medical necessity) or otherwise come within the general defense of necessity. Unnecessary serious bodily harm ought not be disguised as therapeutic medicine.

It is worth bearing in mind that some forms of cosmetic surgery are therapeutic and thus would not be criminalizable because the criteria for criminalization presented in this article are: (I) The surgery is nontherapeutic. (2) The surgery is unreasonable in that it unnecessarily risks harming the patient for no greater end. Thus, the surgeon will have a defense if the nontherapeutic surgery is required as a matter of medical necessity or necessity more generally, such as to serve some other social end as is the case when a surgeon performs a nontherapeutic sterilization on a person suffering from a mental disability to allow the putative consenter to have some sexual autonomy. ${ }^{25}$

Similarly, the surgeon will have a defense where the unnecessary nontherapeutic surgery is reasonable in that it does not result in long-term harm and facilitates the autonomy choices of the consenter, as is the case

24. In Re F. (Mental Patient: Sterilization) [1990] 2 A.C. I.

25. See the discussion in John Stanton-Ife, Mental Disorder and Sexual Consent: Williams and After, in The Sanctity of Life and the Criminal LaW at 204 (Dennis J. Baker et al., eds., 20I3). In exceptional circumstances nontherapeutic surgery is needed as a matter of necessity to prevent social harm to the putative (incapacitated) consenter. See An N.H.S. Trust v. DE [20I3] 3 F.C.R. 343; Re Eve [1986] 2 S.C.R. 388 at 98 ; Re A (Male Sterilization) [2000] I F.L.R. 549. In these cases, the justification for allowing the nontherapeutic surgery seems to be necessity, since the harm involved in sterilization serves the greater good (lesser evil) of allowing the consenter to have some sexual freedom. Necessity seems to permeate the arguments presented by the Lords in In Re F. (Mental Patient: Sterilization) [1990] 2 A.C. I. Cf. the discussion on nontherapeutic abortions in Webster v. Reproductive Health Services (1989) 492 U.S. 490. 
with respect to milder forms of body adornment that are performed on consenting adults. The surgery will be reasonable only if it carries a low risk of resulting in unintended harm. Section 213A of Queensland's Public Health Act 2005, which makes it a criminal offense for surgeons to provide medically unnecessary cosmetic surgery for minors, includes the following useful standard:

The Minister must not recommend to the Governor in Council the making of a regulation under subsection (2) unless the Minister is satisfied that-(a) performance of the procedure on a child is unlikely to compromise the health or safety of the child; and (b) the procedure is routinely performed with minimal adverse outcomes. [Emphasis added.]

One might ask: How can cosmetic surgery be routinely performed without adverse outcomes, if it is never safety-tested? The answer is obvious. It would have to have been applied initially as a last resort in medical necessity cases, as might be the case where surgeons develop a technique for treating those who have suffered injuries in an accident or fire. If such a procedure becomes routine and safe after being used for medical necessities for a period of time, it might evolve to be a form of legitimate nontherapeutic (reasonably) "harmless" cosmetic surgery. ${ }^{26}$ Hence, surgeons can risk grave harm when they are trying to achieve some greater good such as curing a patient, but not when they are merely trying to improve someone's appearance for the sake of serving that person's vanity.

\section{THE LIMITS OF CONSENT AS A DEFENSE FOR UNNECESSARY HARM TO ADULTS}

This article works from the premise that consensual cosmetic surgery can be the result of a putative patient making a fully informed decision and rational choice to have the surgery. ${ }^{27}$ Hence, it is not my aim to explore when consent is rational and informed and therefore valid. There are

26. Nontherapeutic sterilizations are also permissible when they are not a medical necessity, as the procedure has proved to be relatively safe and has minimal long-term health effects. Courts have held that such sterilizations are permissible. See Custodio v. Bauer (1967) 25I Cal. App. 2d 303; Shaheen v. Knight (1957) II Pa. D. \& C. 2d 4I.

27. Cf. Martin Van Hees, Acting Autonomously Versus not Acting Heteronomously, 54(4) Theory \& Decision 337 (2003). 
extreme cases where adults who are addicted to dangerous cosmetic surgery do not make fully rational choices, even though those choices are regarded as autonomous choices under the current law in the United States and Britain. A social environment where people are indoctrinated or influenced to seek a particular image that has been created by society, or some subset of society, can lead to wholly irrational decisions. ${ }^{28}$ Nonetheless, many of these decisions are sufficiently informed to count as autonomous under our current law.

Many cases that are treated as involving autonomous and fully informed decision making are questionable. ${ }^{29}$ Take the example of the "Tiger Man." For some subjective reason the "Tiger Man" thought he would look better as a tiger and had many dangerous and unnecessary cosmetic procedures to make his head appear like that of a tiger. (A Google image search of the Tiger Man will leave most viewers questioning whether the surgeons involved acted reasonably in repeatedly performing dangerous cosmetic procedures for financial gain, without insisting that the Tiger Man seek a purely psychiatric remedy to cure his compulsive obsession to appear as a tiger. ${ }^{30}$ )

There seem to be cases where the validity of the consenter's consent is questionable because of the distorted information that is used by the decision-maker to form the decision to have surgery. Misinformation and unreasonable social influences can lead to irrational decision making. ${ }^{31}$

28. The social information relied on to inform the decision distorts the decision. Compare the discussion in Insoo Hyun, Authentic Values and Individual Autonomy, 35(2) J. VALUe INQUiry 195 (200I).

29. See for example, Yamin v. Commissioner of Social Sec. (2009) F. Supp. 2d, 2009 WL 799457 , where a cosmetic surgeon carried out surgery on a mentally ill woman.

30. On the psychological conditions that might influence decisions to have nontherapeutic surgery, see Cihan Sahin et al., Patient Selection in Plastic Surgery: Recognizing Body Dysmorphic Disorder, 2(2) Archives of Clinical \& Experimental Surgery iog (2013); W. L. Ericksen et al., Psychiatric Issues in Cosmetic Plastic Surgery, 83 Psychiatric Q. 343 (2012); K.A. Phillips, Psychosis in Body Dysmorphic Disorder, 38(I) J. Psychiatric Res. 63 (2004); S. Bellino et al., Dysmorphic Concern Symptoms and Personality Disorders: A Clinical Investigation in Patients Seeking Cosmetic Surgery, I44(I) Psychiatry Res. 73 (2006), where it was observed "that the presence of a psychopathological reaction to imagined defects in appearance in subjects pursuing a surgical correction is associated with the severity of schizotypal and paranoid personality disorders."

3I. Lehrer writes, "there is something odd about the idea that a person who is enslaved by his passions is autonomous." See Keith Lehrer, Reason and Autonomy, 20(2) Soc. POL'y \& PHIL. I77 (2003). 
Nonetheless, in the cases discussed here it is assumed that the consent is valid because it is assumed to have come from a fully informed autonomous adult. In the cases involving minors under the age of $\mathrm{I} 6$, it is assumed their consent is not valid because of their intellectual immaturity. ${ }^{32}$

As we will see, there also is a grey area between adult and minor, because some minors above the age of $\mathrm{I} 6$ and below the age of $\mathrm{I} 8$ are treated as being sufficiently mature to provide valid consent. In these cases, it will be agued that the decision whether or not to have unnecessary nontherapeutic surgery is a decision that a minor between the ages of 16 and 18 should not have to make because they are particularly vulnerable to peer pressure and distorted media messages. Some have argued that minors in this category have less maturity than adults. Whether the latter can be proved or not, few would doubt that minors are more impressionable and vulnerable than adults.

It will be argued in the next section that the age of consent for unnecessary nontherapeutic cosmetic surgery should be I8 years of age, even though some I7-year-olds may be more mature than some 20-year-olds. The line has to be drawn somewhere. To some extent the ability of a mature minor to consent to harmful cosmetic surgery is moot, because consent is no defense for adults or minors where the unnecessary nontherapeutic cosmetic surgery results in grievous bodily harm. To establish this, let us first consider the limits of adult consent as a defense.

The volenti doctrine holds that she who consents is not wrongfully harmed by the harm-doer's conduct. ${ }^{33}$ The limits of the volenti non fit iniuria ("to a willing person, injury is not done") doctrine ${ }^{34}$ were laid down

32. Something that seemed to be overlooked in the old case of Reynolds v. People (I88I) $4 \mathrm{I}$ How. Pr. I79, where the volenti doctrine was allowed as a defense in a case where a I9-yearold man sexually assaulted a I2-year-old girl. Cf. Lawrence v. Lawrence (2010) 36o S.W.3d $4 \mathrm{I} 6$ at 420 . See also the offenses in $\S \S 5-15$ of the Sexual Offenses Act 2003.

33. For a penetrating discussion of the doctrine in the criminal law context, see JoEL Feinberg, Harm to Self: the Moral Limits of the Criminal Law 98-262 (i986).

34. The doctrine has been applied in tort cases for centuries. In Roger Grendon v. The Bishop of Lincoln (1575) 2 Plow. 493 at 50I, it was said: "But if a parson imparsonee presents another, thereby he has disappropriated the advowson, and made it presentable ever after, as Manwood said; for, he said, volenti non fit injuria, but against his will no one can tortiously disappropriate it." See also Bracebridge (I404) Jenk. 73. The rule also has been applied in criminal cases. Coke mentioned it early on in his criminal law volume. See Edward Coke, The Institutes of the Laws of England: Third Part at 8o (i648). 
by the Law Lords in $R . v$. Brown. ${ }^{35}$ (The American courts have taken a broadly similar approach). ${ }^{36}$ Consent is no defense where the defendant has inflicted actual bodily harm or grievous bodily harm upon another, unless the harm results from conduct that comes within one of the exceptions recognized in $R . v$. Brown. The courts have held that harm resulting from legitimate sporting accidents and harm resulting from deliberate violence that is a part of a lawfully recognized violent sport, such as boxing, comes within the exceptions. The courts also have held that trivial harm resulting from lawful correction comes within the exception. ${ }^{37}$ In addition, it has been held that "ephemeral" harm resulting from reasonable body adornment ${ }^{38}$ procedures and from reasonable surgery come within the exceptions. ${ }^{39}$ Coupled with this, it has been held that accidental harm resulting from reasonable horseplay could come within the exception. ${ }^{40}$ The New Zealand Court of Appeal has observed:

The law in the United Kingdom, as stated by the majority in $R . v$. Brown, is that consent is a complete answer in relation to simple assault but not to assault that occasions actual bodily harm, except in recognized categories of cases, including surgery, lawful sports, tattooing and body piercing. Even in cases involving those recognized exceptions, however, it appears that conduct will be criminal, despite consent, where the conduct is sufficiently grave to be characterized as criminal. ${ }^{41}$ [Emphasis added.]

Elsewhere, it has been argued that the decision in $R . v$. Brown is reconcilable with critical morality, because it protects the humanity (dignity) of the consenting party. ${ }^{42}$ Rather than reconsider the debate on whether consent

35. [I994] I A.C. 2 I2.

36. R. v. Brown [1994] I A.C. 212. See also Bass v. State (196I) I20 SE 2d 580; People v. Kevorkian (200I) 248 Mich. App. 373; Commonwealth v. Appleby (1980) 380 Mass. 296; People v. Samuels (1967) 250 Cal. App. 2d 5or.

37. See BAKer, supra note 14 , at Ch. 20.

38. R. v. Wilson [1997] Q.B. 47 at 50 per Russell, L.J.

39. See Bass v. State (196I) I20 SE 2d 580; People v. Kevorkian (200I) 248 Mich. App. 373; Commonwealth v. Appleby (1980) 380 Mass. 296; People v. Samuels (I967) 250 Cal. App. 2d 501 .

40. See generally, BAKER, supra note I4, at Ch. 23.

4I. R. v. Lee [2006] 3 N.Z.L.R. 42 at 9219.

42. Dennis J. Baker, The Moral Limits of Consent as a Defense in the Criminal Law, I2 New Crim. L. Rev. 93 (2009). See also Hamish Stewart, Kantian Police: Limits of Consent in Regulatory Law, I7 New Crim. L. Rev. I (20I4); Hamish Stewart, The Limits of Consent and the Law of Assault, 24 Can. J.L. \& Jurisprudence 205 (2OII). 
can annul the wrongness of wanton harm to others, this article works from the premise that needlessly causing others to suffer grievous bodily harm violates their worth as a human being regardless of whether they desire that degradation of their dignity. Thus, in this article it is taken as a given that wanton serious bodily harm to others violates their dignity as a human being and is wrongful for this reason. Similarly, a court in Germany has held that male circumcision carried out on a minor to satisfy a religious ritual is a violation of the child's integrity. ${ }^{43}$

If a person consents to another throwing acid in her eyes so that she will be left blind for life, she is harmed, even though she may not personally consider herself wronged. To some extent consent can annul wrongness, but it can never neutralize or annul physical harm. Physical harm is something that all species are biologically programmed to avoid. Subjective preferences ${ }^{44}$ and socialization cannot change the biological nature of physical pain or physical damage. Inflicting serious bodily harm upon others injures both the perpetrator and the victim: it damages the perpetrator's character, and it causes direct physical harm to the victim.

Nonetheless, consent is not denied as a defense to prevent self-harm, it is denied as a defense to prevent harm to others. The law does not hold that "you must not harm yourself"; it merely states that others should not rely on your consent to deny you basic respect as a human being. A person is still free to harm herself. That is her personal choice, and the law does not

43. See Jan F. Orth, Explaining the Cologne Circumcision Decision, 77(6) J. CRIM. L. 497 (2013), where $\S 223$ of the German Criminal Code (s. 223 Strafgesetzbuch (StGB)) was invoked. $\S 223$ I I StGB provides: "Whosoever physically assaults or damages the health of another person shall be liable to imprisonment not exceeding five years or a fine." $C f$. Tasmania Law Reform Institute, Non-therapeutic Male Circumcision: Final Report (2012).

44. See J. Slevec \& M. Tiggemann, Attitudes Toward Cosmetic Surgery in Middle-aged Women: Body Image, Aging Anxiety, and the Media, 34(I) Psychol. Women Q. 65 (20I0). Feminists attribute celebrity beauty standards to patriarchal socialization, but such a view is perhaps too simplistic to explain the fuller biological and social motivators behind decisions to have surgery. $C f$. the feminist arguments presented in Michelle Leve \& Lisa Ruben, Cosmetic Surgery and Neoliberalisms: Managing Risk and Responsibility, 22(I) Feminism \& Psychol. 22 (2012); Patricia Gagne \& Deanna McGaughey, Designing Women: Cultural Hegemony and the Exercise of Power Among Women Who have Undergone Elective Mammoplasty, I6(6) Gender \& SOC'y 8I4 (2002); Tamar Wilson, Pharaonic Circumcision under Patriarchy and Breast Augmentation under Phallocentric Capitalism: Similarities and Differences, 8(4) Violence Against Women 495 (2002). 
deny her the freedom to engage in self-harm. ${ }^{45}$ Of course, the state will try to get the self-harmer to accept treatment to prevent her from self-harming. In extreme cases, a person suffering mental illness may be detained in a mental hospital.

It has been argued elsewhere that the Law Lords were too restrictive in denying consent as a defense to both grievous bodily harm (serious physical bodily harm) and actual bodily harm (nonserious physical bodily harm). ${ }^{46}$ It has been argued elsewhere that actual bodily harm is not sufficient to override consent as a defense. It is true that a person who harms another disregards that person's human worth, but human worth is also respected by allowing the putative victim to have the autonomy to choose to be harmed. But any harm has to be reasonable. A person's interest in human dignity has to be balanced against her interest in autonomy. ${ }^{47}$ The human dignity violation involved in inflicting actual bodily harm upon others is not sufficient to outweigh that person's autonomy right. Therefore, consent should provide a defense where the defendant has inflicted actual bodily harm only on the consenting victim. Courts in other jurisdictions have held that consent should be denied as defense only for grievous bodily harm. ${ }^{48}$ That also is the position taken in this article.

Lawmakers' deference to the medical profession has allowed the medical profession to medicalize unnecessary harmful cosmetic surgery, not only for adults, but also for minors. The aim here is to put forward a case for invoking the criminal law to prevent surgeons from carrying out medical

45. In England and Wales, even suicide has been decriminalized. See $§ 2$ of the Suicide Act 196I, which targets harm to others instead of self-harm. Similarly, $\S 2$ of the Female Genital Mutilation Act 2003 (U.K.) makes it an offense for a person to assist a girl or adult woman to mutilate her own genitalia. Self-harm is not criminalized, but assisting another to harm herself is.

46. BAKER, supra note I4, at Ch. 23 .

47. The links between autonomy and dignity are complex, but a deeper analysis of these links is beyond the scope of this article. Cf. R.A. Duff, Harms and Wrongs, 5 Buff. Crim. L. REV. I3 (200I).

48. See the decision of the Supreme Court of Victoria in Neal v. The Queen [20II] V.S.C. A. I72 at 62, where in applying the test formulated in the dissenting judgment of Lord Slynn of Hadley in R. v. Brown [1994] I A.C. 2I2, Redlich, J.J.A., and Kyrou, A.J.A., (Nettle, J.J.A., concurring) said: "The test of mere actual bodily harm has also been criticised in academic writings and, as was pointed out by the New Zealand Court of Appeal in R. v. Lee [2006] 3 N.Z.L.R. 42, 93-94 has in effect not been followed in a number of subsequent English decisions." 
procedures that unnecessarily risk causing harm. In light of $R . v$. Brown, ${ }^{49}$ unnecessary nontherapeutic surgery that carries a high risk of resulting in serious long-term harm for consenting adults is not in the public interest and thus constitutes an aggravated criminal assault contrary to $\S \S \mathrm{I} 8,20$ and 47 of the Offenses Against the Person Act I86I (U.K).

In Attorney-General's Reference (No. 6 of 1980), Lord Lane, C.J., said: "Nothing which we have said is intended to cast doubt upon the accepted legality of properly conducted games and sports, lawful chastisement or correction, reasonable surgical interference, dangerous exhibitions, etc. These apparent exceptions can be justified as involving the exercise of a legal right, in the case of chastisement or correction, or as needed in the public interest, in the other cases" (emphasis added). ${ }^{50}$ The Law Lords in R. v. Brown endorsed Lord Lane C.J.'s "reasonable surgery" defense. ${ }^{51}$ In $R . v$. Brown, ${ }^{52}$ Lord Mustill said that consent was a defense to surgery where the surgery constituted "proper medical treatment." Lord Jauncey held that the consent was a defense for, among other things, reasonable surgery:

Consent of the victim is no answer to anyone charged with the latter offense or with a contravention of section 20 of the Offenses Against the Person Act I86I unless the circumstances fall within one of the well known exceptions such as organized sporting contests and games, parental chastisement or reasonable surgery..$^{53}$ [Emphasis added.]

In In Re F. (Mental Patient: Sterilization), Neill, L.J., said:

It is apparent therefore that the defense of consent is not a complete answer if to give effect to such consent would be against the public interest.... Thus it may be that in some future case the rule that a person may consent to any

49. [1994] I A.C. 212. See also Commonwealth v. Appleby (1980) 380 Mass. 296; People v. Samuels (1967) 250 Cal. App. 2d 5or.

50. [198I] Q.B. 7I5 at 719.

5I. [1994] I A.C. 2 I2.

52. [1994] I A.C. 212 at 266, Lord Mustill said: "Many of the acts done by surgeons would be very serious crimes if done by anyone else, and yet the surgeons incur no liability. Actual consent, or the substitute for consent deemed by the law to exist where an emergency creates a need for action, is an essential element in this immunity; but it cannot be a direct explanation for it, since much of the bodily invasion involved in surgery lies well above any point at which consent could even arguably be regarded as furnishing a defense. Why is this so? The answer must in my opinion be that proper medical treatment, for which actual or deemed consent is a prerequisite, is in a category of its own." (Emphasis added.)

53. [1994] I A.C. 2 I2 at 242. See also Lord Templeman's comments at 23 I. 
operation on himself will require modification if it were to appear that some surgical procedure of an irreversible nature had been carried out not in the course of the medical treatment of the person operated on or of some member of his family ${ }^{54}$ but merely in return for money to meet some pressing financial need. ${ }^{55}$ [Emphasis added.]

One can think of plenty of hypotheticals where surgery is unlawful. For example, consent will not provide a defense to a surgeon where she is involved in nonlegitimate organ harvesting. ${ }^{56}$ An organ donor can consent to having her organs removed after she is dead, but she cannot sell her organs whilst she is alive, nor can she donate an organ when to do so would result in her death. Since a person only has one liver, she would not be able to donate a liver whilst alive, but she could donate one of her kidney's to her sister, if both her kidneys are healthy. A surgeon who illegally removes an organ is more likely to be charged with a specific offense ${ }^{57}$ than with aggravated assault. But there is no reason why a surgeon could not be prosecuted for aggravated assault when she intentionally removes an organ such as a kidney from a consenting victim when the surgeon knows that the kidney is to be illegally sold to another, ${ }^{58}$ because such surgery would not be reasonable surgery and thus would not come within the reasonable surgery exception.

Similarly, if a surgeon were to remove a person's hand to help him perpetrate a fraud, ${ }^{59}$ he or she would be liable for one of the aggravated forms of assault found in $\S \S \mathrm{I} 8,20$, or 47 of the Offense against the Person Act I86I (U.K.) since consent would provide no defense. Consent provides no defense because the hand is not removed for a medical purpose, nor is it removed as a matter of necessity to prevent a person suffering Body Integrity Identity Disorder (BIID) from risking graver harm by trying to amputate it herself by lying her hand or arm on

54. For example, a genuine kidney donation.

55. [1990] 2 A.C. I at 29.

56. See Steven Swinford, Girl Smuggled into Britain to Have Her "Organs Harvested"(THE London Telegraph, Oct. I8, 20I3).

57. See $\S 33$ of the Human Tissue Act 2004; likewise, the surgeon could be charged as an accessory where she assists another to perpetrate the offense found in $\S 32$ of the Act of 2004 . See also $\S$ Io of the Human Transplantation (Wales) Act 2013.

58. On the morality of organ markets, see Mark J. Cherry, Kidney for Sale By Owner: Human Organs, Transplantation, and the Market (2005).

59. State v. Bass (196I) I20 SE 2d 580. 
a railway line. ${ }^{60}$ If a person has attempted to amputate her own foot because a doctor has previously refused to amputate it, the defense of necessity could be raised: the lesser evil would be for the doctor to remove the foot under controlled medical conditions. ${ }^{61}$

The general constraint is one of reasonableness, not one of necessity. After all, some surgery will be reasonable even though it is not necessary, such as minor cosmetic surgery on a consenting adult. Milder forms of cosmetic surgery are likely to be treated as reasonable surgery because it serves the end of allowing the consenter to "adorn" his or her body. ${ }^{62}$ If the cosmetic surgery is not necessary to serve a therapeutic aim (e.g., to cure a burn victim or to correct a growth or congenital abnormality, etc.), then it has to be necessary to serve some other legitimate aim (e.g., a nontherapeutic sterilization of a person with a severe mental incapacity would serve the legitimate end of providing her with some sexual freedom). ${ }^{63}$

However, even unnecessary nontherapeutic surgery may be permissible were it is reasonable in that it results only in ephemeral harm and in a longterm benefit for the consenter as might be the case where a person consents to a nose job. Reasonableness would also depend on success rates. The scientific evidence would have to demonstrate that the procedure is relatively safe and rarely compromises the health or safety of the patient. It also should

6o. Bayne and Levy argue, "if such patients are experiencing significant distress as a consequence of the rare psychological disorder named Body Integrity Identity Disorder (BIID), such operations might be permissible." There are three main disorders that cause young people to desire that their limbs be removed: (I) Body Integrity Identity Disorder involves the consenter not wanting her limbs because she has no awareness of them or believes that they belong to another person. (2) Body Dysmorphic Disorder is a "condition in which the individual believes, incorrectly, that a part of their body is diseased or exceedingly ugly;" and therefore should be removed. (3) Apotemphilia. "Apotemnophiles are sexually attracted to amputees, and sexually excited by the notion that they might become amputees themselves." Tim Bayne \& Neil Levy, Amputees By Choice: Body Integrity Identity Disorder and the Ethics of Amputation, 22(I) J. Applied Phil. 75 at 75-78 (2005).

6I. Cf. People v. Brown (200I) 9I Cal. App. 4th 256. See also David Veale, Outcome of Cosmetic Surgery and "DIY" Surgery in Patients with Body Dysmorphic Disorder, Psychiatric BULL. 2I8 (2000), where it is noted that some mentally disordered people have tried to perform their own cosmetic surgery. See also BAKER, supra note I4, at 824-25; Theodore Bennett, It's But a Flesh Wound: Criminal Law and the Conceptualization of Healthy Limb Amputation, 36 Alternative L.J. I58 (20II).

62. R. v. Wilson [1997] Q.B. 47 at 50, where Russell, L.J., said that acts of violence perpetrated for the sole purpose of adorning the victim could provide a defense.

63. In Re F. (Mental Patient: Sterilization) [1990] 2 A.C. I. 
be demonstrated that it is routinely performed with negligible long-term adverse outcomes. If the procedure results in twenty or thirty percent of those having it suffering from harmful complications, then it would not be reasonable for surgeons to perform it because the risk of harm is high and the risk is not taken in an attempt to rid the patient of some existing medical condition that is causing her harm. It is not a case of the surgeon risking harm as the lesser of two evils. The patient is exposed to the risk of being harmed purely to serve a nontherapeutic or other unreasonable end.

A nose job (rhinoplasty) involves great violence (even when it is intended to cure a genuine medical ailment), but it is carried out under proven safe medical conditions that are designed both to limit the risk of death or long-term injury and to minimize the pain of the operation and the pain of recovery. Coupled with that, the procedure, if carried out properly, should not result in any long-term harm. Generally, nose jobs do not result in high rates of harmful complications, but there always will be a percentage of putative patients who will have ongoing problems. However, this is also the case with therapeutic surgery. Thus, the fact that the complications relate to nontherapeutic surgery is probably not enough to provide a strong harm justification for criminalization.

The rate of complication also depends on the type of procedure performed. Most Westerners have their nose size reduced, but in some Eastern countries people have their nose size increased, which results in more complications because implants are used to increase the nose size. ${ }^{64}$ Notwithstanding this, arguably rhinoplasty provides us with an example of very violent nontherapeutic surgery that does not result in high rates of complications after the putative patient has heeled following the initial surgery. Therefore, it seems the courts would hold that it would be reasonable and thus lawful for a consenting adult to have this kind of surgery.

Whether or not such surgery is reasonable is a question of fact for a jury. The jury is likely to accept that rhinoplasty is reasonable because the violence (serious bodily harm is inflicted under controlled medical conditions and is ephemeral) is a one-off harm that is aimed at providing a longterm benefit. The violence does not result in ongoing harmful side effects

64. See H.R. Jin et al., A Multicenter Evaluation of the Safety of Gore-Tex as an Implant in Asian Rhinoplasty, 20 AM. J. Rhinology 6rs (2006). 
and thus seems to be reasonable nontherapeutic surgery. Does nontherapeutic rhinoplasty come within the medical exception? Or is it a case of adornment? If it is performed merely to change the putative patient's appearance to suit his or her personal preferences, then it is a nonmedical (nontherapeutic) procedure and, thus, cannot come within the medical exception recognized in $R . v$. Brown. ${ }^{65}$ Instead, it would have to be brought under the adornment exception set out in the English Court of Appeal decision in R. v. Wilson. ${ }^{66}$

Generally, unnecessary nontherapeutic surgery that results in the putative patient suffering long-term harmful effects from the surgery is unreasonable surgery. Unnecessary nontherapeutic surgery that carries grave health risks is not lawful under $R . v$. Brown. It has been held for centuries that "[c]onsent was only a limited defense..., because a man could not lawfully consent to unusual violence, and if he asked another man to kill him his request was no defense. It was, for the same reason, unlawful to take a grave risk: as where the deceased requested a man to shoot at him to test his armour, and the armour failed." 67

Risk depends on the gravity of the harm involved and also on the probability of the harm occurring. A high risk of trivial bodily harm resulting from a surgical procedure might be deemed to be a reasonable risk, but a twenty percent chance of serious harm resulting from a surgical procedure that is not a "necessity" would be an unreasonable risk. If twenty percent of those having a particular procedure die or suffer serious bodily harm, then it would be unreasonable surgery. ${ }^{68}$

65. [1994] I A.C. 212.

66. [1997] Q.B. 47 at 50 per Russell, L.J.

67. J.H. Baker, The Reports of Sir John Spelman 3 I2 (1978); see R. v. Emmett (1999) The Times, where the Court of Appeal held: "although consent might form a defense in some circumstances, the risk of non temporary or permanent injury outweighed consent to sadomasochistic practices." See also R. v. Lee [2006] 3 N.Z.L.R. 42 at ๆ 208 passim.

68. R.A. Yoho et al., Review of the Liposuction, Abdominoplasty, and Face-Lift Mortality and Morbidity Risk Literature, 3I(7) Dermatologic Surgery 733 (2005); Susan F. Ely et al., Deaths Related to Liposuction, 340 N. EnG. J. Med. I47I (1999). There also can be other nonfatal results that are very harmful. See Ali Rıza Öreroğlu, Transient Leg Paralysis After Abdominal Liposuction, 34(I) Aesthetic Surgery J. 193 (20I4); see also How Cosmetic Fillers May Cause Blindness (Live Science, Mar. 6, 20I4) http://www.livescience.com/ 43925-in-rare-cases-people-may-lose-eyesight-due-to-facial-enhancement.html. 


\section{THE HARM IN SOME FORMS OF NONTHERAPEUTIC COSMETIC SURGERY}

There are many surgeries that result in harm. It is not possible to list or analyze them all here. It is enough to analyze two examples. The analysis below will analogize unlawful female genital mutilation with lawful labiaplasty in an attempt to show that labiaplasty is a wrongful harm that is lawful only because it has been medicalized by the medical profession. The aim is to demonstrate that they both result in wrongful harm and thus both warrant criminalization. There is a vast amount of literature substantiating the case for criminalizing female genital mutilation, which cannot be surveyed here. What is clear is that female genital mutilation met the wrongful harm criteria for criminalization. It is not only harmful, but also wrong to wantonly mutilate the genitals of another. It is accepted that the state had legitimate justifications for criminalizing female genital mutilation. The aim here is to show that those same moral justifications (wrongful harm) support criminalizing harmful cosmetic surgery.

In many countries medical doctors continue to perform harmful female genital mutilation procedures even though those procedures have been proved to serve no medical purpose. ${ }^{69}$ The procedure is not therapeutic, but to the contrary is physically harmful. It is performed to uphold an antediluvian cultural ritual, not to provide therapy. Female genital mutilation (also called female circumcision) was criminalized because it not only involves gross violence, even if that violence is sometimes carried out under medical conditions, but also because it results in long-term health problems. ${ }^{70}$ It is a form of violence that has been scientifically and medically proven to serve no medical purpose. There also is a wide body of medical and feminist research that demonstrates that it is harmful. ${ }^{71}$ In the rare

69. The World Health Organization has a program aimed at dissuading medical professionals from performing female genital mutilation. See Global Strategy to Stop Healthcare Providers from Performing Female Genital Mutilation (2010).

70. There are some treatments to reverse the harm, but that involves more surgery. Furthermore, these procedures have a limited success rate. See Sarah Creighton et al., Reconstructive Surgery after Female Genital Mutilation, 380 The Lancet 1469 (2012).

7I. Nahid Toubia, Female Circumcision as a Public Health Issue, 33I(II) N. Eng. J. Med. 712-I6 (1994); E. Banks, Female Genital Mutilation and Obstetric Outcome: WHO Collaborative Prospective Study in Six African Countries, 367 The Lancet i835 (2006). 
cases where it serves some medical purpose, the relevant statutory provisions provide a medical purpose defense. ${ }^{72}$

Female circumcision involving infibulations have long-term serious health effects because they interfere with the victim's menstrual and urine flow. In addition, "childbirth adds other risks for infibulated women. ... If deinfibulation is not performed, exit of the fetal head may be obstructed and strong contractions can lead to perineal tears." 73 Female circumcision is akin to unnecessary harmful cosmetic surgery because it aims to serve some cultural norm that has no scientific relation to healthcare.

Female circumcision was criminalized in England and Wales in 2003. ${ }^{74}$ Since the law was enacted a surgeon and his accomplice have been charged under $\S \mathrm{I}(\mathrm{I})$ of the Female Genital Mutilation Act 2003 for performing female genital mutilation surgery on a patient at the Whittington hospital in London. ${ }^{75}$ It is an offense regardless of whether the circumcision is performed by a qualified medical surgeon and regardless of whether the victim is a consenting adult. ${ }^{76}$ The mirror provision in the United States includes an age cap. I8 U.S. Code $\S$ II6 (Female Genital Mutilation) provides: “(a) Except as provided in subsection (b), whoever knowingly circumcises, excises, or infibulates the whole or any part of the labia majora or labia minora or clitoris of another person who has not attained the age of I8 years shall be fined under this title or imprisoned not more than 5 years, or both." The British Parliament decided that the harm involved in female genital mutilation surgery was sufficiently serious to warrant

72. See $\S \S \mathrm{I}(2)(\mathrm{a})$ and (b) of the Female Genital Mutilation Act 2003. The relevant offense in the United States is found in I8 U.S.C.A. § II6. See also Joleen C. Lenihan, $A$ Physician's Dilemma: Legal Ramifications of an Unorthodox Surgery, 35 SAnta Clara L. Rev. 953 (1995); Carla Makhlouf Obermeyer, Female Genital Surgeries: The Known, the Unknown, and the Unknowable, I3 Med. Anthropology Q. 79 (1999).

73. Toubia, supra anote 71. See also Peggy Mulongo et al., Crossing Boarders: Discussing the Evidence Relating to the Mental Health Needs of Women Exposed to Female Genital Mutilation, Internat'l J. Mental Health Nursing i (20I4); Katharina Teufel \& Daniela Marianne Dörfler, Female Genital Circumcision/Mutilation: Implications for Female Urogynaecological Health, 24(I2) Internat'L UROGynecology J. 2O2I (2OI3).

74. § I of the Female Genital Mutilation Act 2003.

75. FGM: UK' First Prosecutions Announced, Crim. L. \& Crim. Just. W KLy. (Mar. 22, 20I4), where it was reported that nearly 4 ,ooo women and girls have been treated for female genital mutilation in London hospitals alone since 2009.

76. The legislation specifically refers to girls, but $\S 6(\mathrm{I})$ of the Female Genital Mutilation Act 2003 provides: "Girl includes woman." 
excluding consent from operating as a defense for a surgeon carrying out this kind of surgical procedure, even where the consent is from an informed adult.

Now let us consider an example of unnecessary surgical harm that has not been criminalized because it has been medicalized. Genital cosmetic surgery is widely practiced in the United Kingdom. Women and young girls, as young as eleven, have been seeking genital cosmetic surgery for the purpose of having a "designer vagina." 77 Genital cosmetic surgery is performed not only on consenting adults, but also on minors. The most common procedure is labiaplasty. A body of compelling medical evidence demonstrates its long-term adverse health consequences. ${ }^{78}$ It also has been demonstrated that in nearly all cases it is not carried out to cure a genuine health problem, but instead to serve the subjective preferences of the (putative patient) victim ${ }^{79}$ or her family. ${ }^{80}$

At team of leading medical experts have reported:

The absence of a lower age limit for any of the female genital cosmetic surgery (FGCS) procedures is most disturbing of all. In the past 6 years, 343 labiaplasties were performed in the UK NHS on girls aged I4 or under. The

77. N.S. Crouch et al., Clinical Characteristics of Well Women Seeking Labial Reduction Surgery: A Prospective Study, in8(i2) Bjog: An Internat'l J. Obstetrics \& GynaeCOLOGY 1507 at I5IO (20II), where it is reported: "Younger girls may not be able to understand the potential long-term risks of surgery on sensation or be able to appropriately weigh up the risks and benefits of such an unstudied procedure.... If anything, scientific studies suggest that genital surgery is associated with reduced sensitivity, which could affect sexual function. Recently, oestrogen receptors have been demonstrated at the free edge of the labia minora, which would be disrupted during surgery." It also was reported at 1507 that "[d]espite reassurances that their labia were normal, $40 \%$ of the participants remained keen to pursue surgery by any other available route."

78. See Adams, supra note 9 at 52, where it is reported: "This procedure should not be carried out in women younger than I8 years of age because the shape of their external genitalia is still changing during puberty."

79. B.E. Hayden et al., Labial Reduction in Adolescent Population-A Case Series Study, 22(I) J. Pediatric \& Adolescent Gynecology 53 (2009), where it is reported that most of these surgeries are carried for cosmetic purposes where the minor is embarrassed of her natural state. See also R. Bramwell et al., Expectations and Experience of Labial Reduction: a Qualitative Study, Ii4(I2) Bjog: An Internat'l J. Obstetrics \& Gynaecology i493 (2007).

8o. For example, harmful male circumcision is performed on infants to satisfy the religious beliefs of their parents. On the ethics of male circumcision, see Abbie J. Chessler, Justifying the Unjustifiable: Rite v. Wrong, 45 Buff. L. Rev. 555 (1997). 
indications for surgery in this group of children are unknown, but labial anomalies requiring surgical interventions are extremely rare. In addition, significant numbers of labiaplasties on girls under 18 years of age are reported in the medical literature with publications dwelling specifically on labial reductions in adolescents for hypertrophy or asymmetry of the labia minora. In a recent observational study of referral patterns, girls as young as 9 years with normal labia had presented for labiaplasty. The labia minora change as part of normal pubertal growth with development completed as the individual approaches adulthood. Given the fact that anatomy continues to change throughout the lifespan, the younger a girl begins her FGCS journey, the higher the number of lifetime operations and the greater and more multiple the risks. ${ }^{81}$

Surgeons motivated by monetary compensation seem to be willing to perform these harmful operations as a quick fix for self-esteem issues, when psychological counseling would provide a harmless cure. There may be rare cases where labiaplasty is a medical necessity, but the empirical evidence demonstrates that most cases do not involve medical necessity.

There are many other examples of nontherapeutic cosmetic procedures that have high rates of long-term complications, such as breast augmentations, ${ }^{82}$ but space constraints do not allow for a detailed discussion of them all. Measuring harm is difficult: We have to not only consider the intentional violence involved in surgery, which is immediately harmful, but also the risk of long-term harm that the particular surgery carries. There are two sets of risks at play: (I) the risk of complications during surgery, and (2) the risk of complications following surgery. But there is only one initial act of intentional violence, which is the surgery itself.

All surgery including unnecessary cosmetic surgery has inherent risks. There is a risk that the surgeon will not be properly qualified or the clinic not properly equipped, but the focus here is only on the risks that are involved when the surgeon is qualified and when the surgical operation takes place in a properly equipped clinic. ${ }^{83}$ Even where the surgeon is

8I. See also Lih-Mei Liao et al., An Analysis of the Content and Clinical Implications of Online Advertisements for Female Genital Cosmetic Surgery, B.M.J. Open (2012) (2: eoorgo8 doi:Io.II36/bmjopen-20I2-0oI9o8).

82. For a discussion of the harms involved, see Diana Zuckerman, Teenagers and Cosmetic Surgery: Focus on Breast Augmentation and Liposuction, 43(4) J. Adolescent Health 318 (2008).

83. Cf. People v. Brown (200I) 9I Cal. App. 4th 256, where the surgeon lacked proper qualifications and operated without proper facilities. Nigel Mercer, the President of the 
qualified and is operating in excellent clinical conditions, there are inherent risks in all forms of surgery. Surgery not only involves the violent act of cutting and incising, tearing, disjointing, and so on, but also the risk that those acts, even though performed under the safest medical conditions available, could result in the patient dying on the operating table or suffering from complications.

During surgery the patient might suffer from profuse bleeding or from an adverse or insufficient reaction to the anesthesia. Coupled with that, the doctor might accidentally or negligently cause unintended harm. Following the surgery the patient might suffer from an infection, blood clots, pain from the operation, and so on. These risks might be acceptable when a person has to take the risk for necessary medical surgery that is aimed at serving a greater therapeutic end, but they seem unacceptable risks for a person to be exposed to for the purpose of having unnecessary nontherapeutic surgery.

There is also the risk of complications following the relevant surgery. Some of these complications will relate directly to the surgery, others will result months or years later. The harmfulness of the complications will depend on the particular complication and surgical procedure that caused it. Some procedures result in fairly harmful complications and also have high rates of these complications. For example, it has been reported that breast augmentations require follow-up procedures and result in higher suicide rates. ${ }^{84}$ The short-term and also long-term complication rates for some forms of surgery are very high. ${ }^{85}$ The U.S. Food and Drug

British Association of Aesthetic Plastic Surgeons, provided a warning of the dangers of unqualified cosmetic surgeons. See Nigel Mercer, Dangers of "Lax" Cosmetic Surgery Rules, (Bвс News, Feb. 3, 20I0).

84. Elizabeth Morgan, Suicide After Breast Augmentation, i9(3) Epidemiology 520 (2008).

85. P.S. Walker et al., Natrelle Saline-filled Breast Implants: a Prospective Io-Year Study, 29(I) Aesthetic Surgery J. ig (2009); Stuart Bondurant Et Al., Safety of Silicone Breast Implants By Committee on the Safety of Silicone Breast Implants (200o); Marcia Angell, Evaluating the Health Risks of Breast Implants: The Interplay of Medical Science, the Law, and Public Opinion, 334 New EnG. J. Med. I5I3 (1996); Ian C. Hoppe et al., Case Report: Localized Scleroderma of the Breast After Saline Implant Rupture, 32(2) Eur. J. Plastic Surgery 127 (20II); Marisa Marques et al., Long-Term Follow-Up of Breast Capsule Contracture Rates in Cosmetic and Reconstructive Cases, I26(3) Plastic \& Reconstructive Surgery 769 (20I0); Neal Handel et al., Breast Implant Rupture: Causes, Incidence, Clinical Impact, and Management, I32(5) Plastic \& Reconstructive Surgery 
Administration has reported, "Breast implants are not lifetime devices. The longer a woman has... implants, the more likely she is to experience complications. One in 5 patients $(20 \%)$ who received implants for breast augmentation will need them removed within Io years of implantation." 86

A harm analysis requires the lawmaker to consider both the frequency and gravity of the complications from unnecessary nontherapeutic cosmetic surgery. Breast augmentations result in a high rate of complications, and the complications are of a serious nature. It is difficult to see how allowing a surgeon to carry out nontherapeutic breast augmentation procedures can be reconciled with common law authorities such as $R$. $v$. Brown ${ }^{87}$ and Bass v. State, ${ }^{88}$ given the high rate of complications and given the gravity of the harm that is inherent in those complications; a fortiori in the context of minors receiving such surgery.

It is difficult to see how the violent amputation involved in labiaplasties $^{89}$ can be reconciled with $R . v$. Brown or Bass $v$. State, given that it has been medically proven that " $\mathrm{t}]$ he younger a girl begins her labiaplasty trajectory, the higher the number of operations over her life time and the greater the risk of scarring and sensitivity loss." ${ }^{\circ 0}$ Space does not allow for a more detailed harms analysis, but I think sufficient evidence has been cited for a moral philosopher to work from the presumption that if such procedures are harmful, unnecessary, and a wrongful violation of the consenter's dignity, criminalization is appropriate. These forms of nontherapeutic cosmetic surgery are harmful, both immediately and in the patient's future.

Per contra, reasonable adornment involving one-off violence that does not result in any long-term harmful complications might be treated as

II28 (20I3); P. Fryzek et al., Local Complications and Subsequent Symptom Reporting among Women with Cosmetic Breast Implants, Io7(I) Plastic \& Reconstructive Surgery 2I4 (200I).

86. U.S. Food \& Drug Administration, "FDA Provides Updated Safety Data on Silicone Gel-filled Breast Implants,” (News Release), http://www.fda.gov/NewsEvents/Newsroom/ PressAnnouncements/ucm260235.htm.

87. [I994] I A.C. $2 \mathrm{I} 2$.

88. (I96I) I20 SE 2d 580.

89. In the amputation technique or "labial trim," the edge of the labium is cut out and the edges oversewn. See British Society for Paediatric \& Adolescent Gynecology, Labial Reduction Surgery (Labiaplasty) on Adolescents (Position Statement, Oct. 2013).

90. British Society for Pediatric \& Adolescent Gynecology Labial Reduction Surgery (Labiaplasty) on Adolescents (Position Statement, Oct. 2013). 
lawful, even though it involves ephemeral serious bodily harm that is inflicted in controlled medical conditions. For example, since rhinoplasty has minimal adverse complications and a good recovery rate, it might be treated as lawful even though it involves ephemeral serious bodily harm. The same cannot be said of adornment procedures that have high rates of complications and frequently result in harm over a longer period of time, as seems to be the case with breast augmentation procedures and labial reduction surgeries.

In the English Court of Appeal decision in R. v. Wilson, ${ }^{91}$ a husband used a hot knife to brand his initials on his wife's buttocks because she asked him to brand her. Wilson was charged with assault occasioning bodily harm contrary to $\S 47$ of the Offenses Against the Person Act I86I (U.K.), but his conviction was quashed on appeal. The appeal succeeded because his actions were held to come within the purview of the recognized exceptions laid down in $R . v$. Brown. The English Court of Appeal held that the branding was comparable to tattooing and thus was a form of reasonable adornment.

It seems clear that if the branding had been $u n$-reasonable adornment, the decision in $R . v$. Wilson would have been different. So what made it reasonable? The Court does not provide any insights, but it is arguable that reasonable adornment is a body adornment procedure that is not unreasonably dangerous in that it carries a low probability of resulting in serious complications in the longer term. A branding is likely to heal within a weak and thereafter cause the person branded no further complications. It does not pose a risk to the life of the person receiving the brand, nor does it risk causing him or her serious injury. It is one-off violence that results in no long-term harm, but allows the receiver the autonomy to chose to adorn him or herself for the long-term.

The wrongful harm criteria are difficult to apply because surgeons tend to argue that the harmful surgery is needed because the putative patient will suffer psychological distress if it is not provided. Medical necessity provides a defense, but this defense only applies where the surgery is carried out as a matter of medical/therapeutic necessity. ${ }^{92}$ Physicians should not be allowed to medicalize gross harm that serves no medical or therapeutic

91. [1997] Q.B. 47.

92. "In general, a serious medical need is 'one that has been diagnosed by a physician as mandating treatment, or one that is so obvious that even a lay person would easily recognize 
purpose. Surgeons and other medical practitioners do not have carte blanche to inflict harm on others under the disguise of medicine. The medicine must be therapeutic and necessary or otherwise come within the reasonable adornment exception. In addition, the general defense of necessity would cover nontherapeutic sterilizations on those suffering from a mental disability, for example. Likewise, since sterilizations can be carried out safely with a low rate of long-term harmful effects, a person should have the freedom to have one. In such a case, a person's autonomous decision to have such a procedure enhances her dignity rather than degrades it.

It is arguable that adults should have the freedom to have some unnecessary cosmetic surgery, so long as the surgery only risks ephemeral harm and serves the utility of being either medicine or "reasonable" adornment. Adornment could cover a one-off procedure that results in long-term adornment, where that procedure has minimal long-term adverse health effects for the putative patient. But minors should not be allowed to have unnecessary cosmetic surgery under any circumstances. A wealth of examples might be provided, but the few examples presented are sufficient for making the case for criminalizing unnecessary cosmetic surgery when it carries a high risk of serious harm.

The medical profession has medicalized these unnecessary procedures by claiming they are necessary for the victim's psychological health. If this is the case, then the burden is on the medical profession to prove that invasive surgery is the only available treatment and that it is the lesser of two evils. If a person is suffering mental anguish because of her body image, then the appropriate medical response would be to provide psychological counseling, not invasive surgery involving serious bodily harm and long-term harmful complications.

The medical profession has the burden of proving that psychological counseling does not work and that the harm to the victim would be greater without the invasive surgery than with it. It is submitted that such a burden is not likely to be satisfied, because the medical science points in the other direction. The medical science demonstrates that these invasive procedures are not only harmful in the short-term (the surgery itself involves serious violence and immense pain in the short-term), but also expose the victims 
to long-term complications of a very harmful nature. There is a wealth of evidence to support the claim that labiaplasty and breast enlargement surgery are very rarely needed as a matter of medical necessity, and that they are nearly always provided in circumstances where they are not medically necessary. In these cases psychological counseling would provide an effective alternative. Psychological counseling might not be one hundred percent effective in every case, but the evidence suggests that invasive surgery is far less effective. Physicians should not be allowed to do more harm than good with the ulterior aim of making money, which is what they do when they provide surgery to satisfy a child's naïve whims to have a certain physical image.

\section{A. The Limits of Consent as a Defense for Harm to Minors}

If an adult cannot consent to the sort of wrongful harm that is involved in unnecessary nontherapeutic cosmetic surgery that carries a high risk of serious harm, a fortiori a minor cannot consent to such harm. The decision to criminalize cosmetic surgery that unnecessarily risks causing long-term harm to minors does not rest simply on their having less capacity to make an informed decision about whether or not to have the surgery; it also rests on the public interest justification ${ }^{93}$ for denying consent as a defense where the consenter is a member of a vulnerable group in our society. The core justification for criminalizing those who perform unnecessary cosmetic surgery on minors is that such surgery involves wrongful harm-doing. A minor's vulnerability and mental immaturity are additional factors that lend weight to the case for using the criminal law to prevent surgeons from performing such procedures on minors.

It was recognized nearly two hundred years ago that minors achieve varying degrees of capacity. ${ }^{94}$ It is true that there is no clear line between minor and adult, so an arbitrary legal line has to be drawn to protect the majority. It does not matter that some minors are mentally mature at the

93. Public interest has long provided a justification for state intervention; see Matthew v. Ollerton (1693) Comb. 218, where it was said: "The defendant may refer to the plaintiff himself, if he will; but license to beat me is void, because 'tis against the peace."

94. See R. v. Smith (1845) I Cox C.C. 260; R. v. Gorrie (1919) 83 J.P. 136; Guarro v. U.S. (1956) 237 F. 2d 578; Com. v. Feijoo (1995) 646 N.E. 2d II8. "A six-year-old girl is incapable, in law, of giving her consent to indecent liberties taken with her." Lenahan v. Commonwealth (1946) 30I Ky. 714. See also the Sexual Offenses Act 2003 U.K.). 
age of 17 , while some adults are mentally immature at the age of 25 . The law aims to protect the majority, and the majority of those aged I7 and under are less mature than those aged 18 and above. A blanket ban against all those between the ages of 16 and I8 being allowed to consent to unnecessary harmful cosmetic surgery rests not only on their diminished capacity, but also on a policy choice to protect impressionable and vulnerable minors from being subjected to the irreversible harm that is likely to result from their making a decision that they might not otherwise make, but for their impressionable age. "Youth is easily deceived because it is quick to hope," said Aristotle. Perhaps no person's decisions are more influenced by peer pressure than those of a teenager. Peer pressure and impressionability leads even mature minors to make regrettable and bad decisions. They tend to take risks that would not necessarily be taken by adults. ${ }^{95}$ When it can be demonstrated that the planned surgery serves no therapeutic end and is potentially very harmful, there seems to be no great restriction upon the liberty of the minor by having a blanket ban against such surgery for minors. The evidence would have to show that the planned surgery is potentially harmful and serves no therapeutic end. Such an approach has been adopted in the state of Queensland in Australia. ${ }^{96}$

It is absurd that in England and Wales a minor cannot consent to having a tattoo, ${ }^{97}$ but she can consent to, inter alia, having invasive surgery to augment her breasts or harmful nontherapeutic labiaplasty. ${ }^{98}$ In Burrell $v$. Harmer $^{99}$ a tattooist tattooed two boys aged $\mathrm{I} 2$ and $\mathrm{I} 3$, causing their arms to become inflamed and painful. The magistrates convicted him of an assault occasioning actual bodily harm, rejecting his defense that the boys consented on the ground that they did not understand the nature of the act; and the conviction was upheld on appeal. These boys did not expect the painful result. But it is difficult to see how the doctrine of consent can

95. Research shows that teenagers are more likely than adults to take risks. See Laurence Steinberg, Risk Taking in Adolescence New Perspectives From Brain and Behavioral Science, i6(2) Current Directions in Psychol. Sci. 55 (2007).

96. See $\S 213 \mathrm{~B}$ of the Pubic Health Act 2005. See also Dan O'Connor, A Choice to Which Adolescents Should not be Exposed: Cosmetic Surgery as Satire, I5 J. Health Care L. \& POL'y 157 (2012).

97. $\S$ I of the Tattooing of Minors Act 1969, applied in Harvie v. Stewart (2010) G.W.D. $27-533$.

98. Gillick v. West Norfolk and Wisbech AHA [1986] A.C. II2.

99. [1967] Crim. L.R. I69. 
rationally distinguish between a cosmetic surgeon who performs cosmetic surgery that risks unnecessary harm and a tattooist, and equally hard to imagine that the courts can continue to allow harmful unnecessary nontherapeutic surgery to go unregulated.

A surgical operation on the body of a minor is a criminal battery, even if it has a good result for the victim, ${ }^{100}$ unless the patient or some authorized person consents to it on her behalf. ${ }^{101}$ This is recognized both in the United States and the United Kingdom. In the United Kingdom, § 8 of the Family Law Reform Act 1969 allows a minor over the age of 16 to consent to medical treatment without her parent's permission, but the consent must be informed and genuine. ${ }^{102}$ If the minor has not reached the age of $\mathrm{i} 6$, consent without her parents' input would be valid only if she satisfies the "mature minor" test. ${ }^{103}$ When it is in the best interests of the minor to receive medical treatment, ${ }^{104}$ other interested parties could apply to the court to seek a declaration to ensure that it is lawful to provide the treatment without the consent of the minor and her parents. ${ }^{105}$ In Re E (A Minor) (Wardship: Medical Treatment) ${ }^{106}$ an English court held that it was lawful for the doctors to give the minor a blood transfusion, even though neither the child nor his parents wanted him to have it. The child would need to be within the jurisdiction of the court before it could make such an order. ${ }^{107}$ Generally, the courts have an inherent jurisdiction, ${ }^{108}$

Ioo. R. v. Brown [1994] I A.C. 212. See also Bass v. State (196I) I20 SE 2d 580; People v. Kevorkian (200I) 248 Mich. App. 373; Commonwealth v. Appleby (1980) 380 Mass. 296; People v. Samuels (1967) 250 Cal. App. 2d 5or.

IOI. Younts v. St. Francis Hospital \& School of Nursing, Inc. (1970) 205 Kan. 292.

IO2. For a penetrating discussion of the law, see Stephen Gilmore \& Jonathan Herring, "No" is the Hardest Word: Consent and Children's Autonomy, 23(I) CHILD \& FAM. Q.3 (2OII).

I03. Gillick v. West Norfolk and Wisbech AHA [1986] A.C. II2.

I04. Lambert v. Wicklund (1997) 520 U.S. 292.

I05. This is the law in both England and in most of the United States. In Bellotti v. Baird (1979), 443 U.S. 622 at 648 , it was said: "If, all things considered, the court determines that an abortion is in the minor's best interests, she is entitled to court authorization without any parental involvement." For the position in England and Wales, see Gillick v. West Norfolk and Wisbech AHA [1986] A.C. II2.

I06. [1994] 5 Med. L.R. 73.

107. The law is essentially the same in the United States. See San Joaquin County Human Services Agency v. Marcus W. (2010) I85 Cal. App. 4th I82; J.N. v. Superior Court (2007) 156 Cal.App.4th 523.

I08. DL v. A Local Authority [2012] 3 W.L.R. I439. In Earl of Shaftsbury v. Shaftsbury (I725) Gilb. Ch. I72 at $173-74$, it was said: "But the Crown has another Jurisdiction, and 
which allows them to make a declaration that a proposed operation is in a patient's best interests. In Matter of Grady, it was said:

The parens patriae power of our courts derives from the inherent equitable authority of the sovereign to protect those persons within the state who cannot protect themselves because of an innate legal disability. While traditionally used to protect the economic and property interests of the legally disabled, it has also been invoked to protect personal rights.... Parens patriae jurisdiction has been invoked in cases involving substituted consent for medical procedures. The most common of these occurs when a court authorizes a blood transfusion over the objections of an injured or sick child's parents. Occasionally courts have authorized substituted consent for an incompetent adult to undergo medical treatment. ${ }^{109}$

Where a minor is a ward of the court or of the state, the court will have jurisdiction to authorize medical treatment. Wardship is a legal mechanism that allows the courts to exercise parens patriae powers in relation to minors. ${ }^{110}$ As a general rule in the absence of an emergency or unanticipated conditions arising during surgery, a physician or surgeon must obtain the consent of the patient before treating or operating on her. If the patient is incapable of consenting, then consent must be obtained from a court or a person who is legally authorized to consent on the patient's behalf. ${ }^{111}$

The British Law Commission proposed "to enact special rules relating to consent purportedly given by persons under 18 or with mental disabilities and suggested a broadening of the type of conduct that may nullify consent. It also proposed that the consent of persons under 18 to any level of intentionally inflicted injuries for sexual, religious or spiritual purposes should not in any circumstances be treated as a valid consent" (emphasis added). ${ }^{112}$ Nontherapeutic surgery that risks unnecessary harm seems to

that is as Pater Patriœ, as a Father over his Children... The King has a Right to take Care of Infants, Lunaticks, and Ideots, that cannot take Care of themselves; and this Care cannot be exercised otherwise than by appointing them proper Curators or Committees. . . Now as the King has the Protection of Infants, I don't see any other Protection can be, than by assigning them their Guardians; and where should that Protection be exercised, but in that Court where Care is taken of all Persons under natural Disabilities?" See also Cary v. Bertie (1696) 2 Vern. 333 at 342.

I09. (I98I) 85 N.J. 235 at 259.

IIO. In re N. (Infants) [1967] Ch. 512.

III. In Re F. (Mental Patient: Sterilization) [1990] 2 A.C. I.

II2. R. v. Lee [2006] 3 N.Z.L.R. 42 at 9 228, citing Law Commission for England and Wales, Criminal Law: Consent in the Criminal Law (L.C.C.P. I39, 1995) at 9 Io.I-Io.I5. 
be an area where consent from a person under the age of I8 years should be deemed to be invalid consent, even if it is technically valid because the mature minor understands the implications of her decision. The majority of the states in the United States require adolescents to be 18 and over before they can give valid medical consent. It is not proposed that the mature minor test be abandoned for harm prevention decisions such as the decision to have necessary medical treatment, because in practice, when the test is applied in controversial medical cases, "parental consent" and "mature minor" consent is subject to judicial scrutiny. Coupled with this, such decisions are aimed at preventing harm, not at unnecessarily risking harm.

More generally, if the court concludes that the minor's refusal to have necessary medical treatment is likely to harm her, then it is likely to hold that such a decision is irrational and therefore is not a decision that a mature minor would make. ${ }^{113}$ In everyday life minors routinely consent to have medical treatment and also to have nontherapeutic cosmetic surgery that risks unnecessary harm without their decisions ${ }^{114}$ being subjected to judicial scrutiny. In most cases, cosmetic surgeons have treated parental approval as being sufficient. However, sometimes parents, because of their own insecurities, will be responsible for forcing their children to have unnecessary (harmful) cosmetic surgery. ${ }^{115}$ Thus, a blanket ban is needed to protect children not only from their own foolish decisions, but also from

See also Michele Deitch et al., Seventeen going on Eighteen: An Operational and Fiscal Analysis of a Proposal to Raise the Age of Juvenile Jurisdiction in Texas, 40 AM. J. CRIM. L. I (20I2).

II3. Re E (A Minor) (Wardship: Medical Treatment) [1994] 5 Med. L.R. 73. Analogously, in In Re F. (Mental Patient: Sterilization) [1990] 2 A.C. I at 64, Lord Brandon said: "What is required from the court is rather an order which establishes by judicial process (the 'third opinion' so aptly referred to by Lord Donaldson of Lymington M.R.) whether the proposed operation is in the best interests of the patient and therefore lawful, or not in the patient's best interests and therefore unlawful." See also Matter of Schiller (1977) I48 N.J. Super. 168 (where the court authorized the amputation of a leg). For a comprehensive digest of the law in the United States, see Power of Court or Other Public Agency to Order Medical Treatment over Parental Religious Objections for Child Whose Life is not Immediately Endangered, 2I A.L.R. 5th 248 (20I4); Medical Practitioner's Liability for Treatment Given to Child Without Parent's Consent, 67 A.L.R. 4th 5II (20I4).

II4. "What may seem the most unusual figure for British audiences are the number of teenagers getting treated. Although it's only $2 \%$ of the total, that's still 230,617 procedures in a year." U.S. Plastic Surgery Statistics: Chins, Buttocks and Breasts up, Ears down, (THE Guardian, Datablog, Apr. 19, 20I2).

II5. Alicia Ouellette, Eyes Wide Open: Surgery to Westernize the Eyes of an Asian Child, 39(i) Hastings Centre Rep. I5 at i6 (2009). 
foolish decisions made by their parents. A parent cannot authorize her I4-year-old to purchase alcohol or to smoke cigarettes, so why should she be able to authorize nontherapeutic cosmetic surgery that involves a high risk of harming her child? As far as genuine medical consent is concerned, parental consent is more likely to have a harm prevention rationale and, therefore, is not as controversial. A blanket ban against nontherapeutic cosmetic surgery is needed to prevent either parental or mature minor consent being used to make such surgery permissible. ${ }^{116}$

What is being proposed is that the mature minor test be abandoned for cases involving unnecessary nontherapeutic cosmetic surgery that risks harm. The mature minor test has been the subject of sustained judicial ${ }^{117}$ and academic criticism. ${ }^{118}$ Its use to allow minors to be put in a position where they have to choose whether or not to have unnecessary cosmetic surgery that carries a risk of causing them permanent injury is unacceptable. Genuine medicine is different since the minor is put in the position where she has to choose, because of a chance medical condition. When a "mature minor" has to choose whether or not to have necessary medical treatment to save her life or to cure some greater harm, it is not objectionable to let her have as much input as possible. Similarly, where a mature

II6. Mark J. Cherry, Ignoring the Data and Endangering Children: Why the Mature Minor Standard for Medical Decision Making Must be Abandoned, 38(3) J. Med. Philos. 315 at 323 (2013).

II7. See Miller v. Alabama (20I2) I32 S.Ct. 2455 at 2469, where Kagan, J. (delivering the opinion of the Court, in which Kennedy, Ginsburg, Breyer, and Sotomayor, J.J., joined) said: "But given all we have said in Roper, Graham, and this decision about children's diminished culpability and heightened capacity for change, we think appropriate occasions for sentencing juveniles to this harshest possible penalty will be uncommon. ... Although we do not foreclose a sentencer's ability to make that judgment in homicide cases, we require it to take into account how children are different, and how those differences counsel against irrevocably sentencing them to a lifetime in prison." See also Liao, supra note 8I; U.S. v. Shill (2014) 740 F. 3d 1347 at 1356; People v. Willis (2013) 997 N.E. 2d 947 at 959; Graham v. Florida (20IO) I30 S.Ct. 20II; Roper v. Simmons (2005) I25 S.Ct. II83; In re Alatriste (20I3) I63 Cal. Rptr. 3d 748.

II8. Jay D. Aronson, Neuroscience and Juvenile Justice, 42 Akron L. Rev. 917 (2009); Ruben C. Gur, Brain Maturation and Its Relevance to Understanding Criminal Culpability of Juveniles, 7 Current Psychiatry Rep. 292 (2005); Staci A. Gruber \& Deborah YurgelunTodd, Neurobiology and the Law: A Role in Juvenile Justice?, 3 Oнiо St. J. Crim. L. 32; Christopher Thompson, The Development of Decision Making Capacities in Children and Adolescents: Psychological and Neurological Perspectives and Their Implications for Juvenile Defendants, 27 BeHAV. SCI. \& L. I73. (2009) 
minor makes a harm prevention decision, such as the decision to purchase prophylactics to avoid contracting sexually transmitted diseases, there is nothing objectionable about allowing her to make this sort of decision. If her parents are involved, because of embarrassment, she may be deterred from making a decision that is designed to prevent her from being harmed. This is very different from letting her make a borderline autonomous decision that unnecessarily exposes her to the risk of suffering harm that serves no reasonable objective.

Courts and legislatures in the United States have accepted that the scientific evidence overwhelmingly demonstrates that there is a difference in the maturity of a mature minor and an adult. ${ }^{119}$ The United States Supreme Court has gone as far as accepting that a person's age could impact her degree of culpability. In the United Kingdom, Parliament has held that those between the ages of $\mathrm{I} 6$ and $\mathrm{I} 8$ cannot give a valid consent to sexual intercourse where the other party is in a position of trust, as is the case where the other party is her school teacher. ${ }^{120}$

In taking this step, the Parliament of the United Kingdom seems to accept that those aged between 16 and $\mathrm{I} 8$ are not sufficiently mature to give valid consent when they are under the influence of a person who might have more than normal influence. Invaliding the sexual consent of I6- or I7-year-olds who consent to have sexual relations with their schoolteachers rests on the rationale that those under 18 lack full capacity to make a fully

II9. Roper v. Simmons (2005) I25 S.Ct. II83 at II95, where Kennedy, J., said: "Three general differences between juveniles under $\mathrm{I} 8$ and adults demonstrate that juvenile offenders cannot with reliability be classified among the worst offenders. First, as any parent knows and as the scientific and sociological studies the respondent and his amici cite tend to confirm, '[a] lack of maturity and an underdeveloped sense of responsibility are found in youth more often than in adults and are more understandable among the young. These qualities often result in impetuous and ill-considered actions and decisions.' ... ('Even the normal I6-year-old customarily lacks the maturity of an adult'). It has been noted that 'adolescents are overrepresented statistically in virtually every category of reckless behavior.' ... In recognition of the comparative immaturity and irresponsibility of juveniles, almost every State prohibits those under I8 years of age from voting, serving on juries, or marrying without parental consent. See Appendixes B-D, infra." See also William J. Katt, Roper and the Scientific Amicus, 49 Jurimetrics J. 253 (2009).

I20. § 2I of the Sexual Offenses Act 2003 (U.K.) "defines 'positions of trust' for the purposes of sections I6 to I9 of the Act as covering relationships such as teacher and pupil or doctor and patient." R. v. McNally [20I4] 2 W.L.R. 200 at 2I2. See also BAKER, supra note I4, at 9 IO-O4I. 
independent decision. ${ }^{121}$ If the same student were to have an affair with a university professor a year after leaving school, there would be no criminal liability for the professor, notwithstanding the "position of trust" issue, because Parliament deems that I8-year-olds have sufficient capacity to choose whom to have an affair with, even where there may be a power imbalance in the relationship. A similar situation is when an adult secretary has an affair with his or her boss.

In State v. Windom, Jones, J., said:

The U.S. Supreme Court's views align with the consensus emerging in the scholarly literature that adolescents are not as able as adults to act responsibly.... Their ability to think logically deteriorates, however, in emotionally charged or stressful situations. Further, "[e]ven though adolescents, by age sixteen, exhibit intellectual abilities comparable with adults, they do not develop the psycho-social maturity, ability to exercise selfcontrol, and competence to make adult-quality choices until their early twenties." 122

The decisions of the Supreme Court of the United States and the scientific and medical literature ${ }^{123}$ on the subject of adolescent capacity demonstrates that adolescents are inherently less mature than adults in ways that require them to be protected from some of their own decisions. The conclusion of the Supreme Court of the United States marks a departure from the cases advocating the mature minor doctrine. The mature minor doctrine is used to deem that teenagers have the same mental capacity as adults and thus should be given the same freedom as an adult to make life choices. The mature minor test allows minors to be treated as though they have the same capacity as an experienced adult when it comes to making

I2I. R. v. Lamb [2007] EWCA Crim. I766; R. v. Lister [2006] i Cr. App. R. (S.) 69; R. v. Healy [20I0] i Cr. App. R. (S.) IO5.

I22. (2OII) I50 Idaho 873 at 888 .

123. Ana S. Iltis, Parents, Adolescents, and Consent for Research Participation, 38(3) J. Med. \& Phil. 334 (2013); Evan A. Wilhelms \& Valerie F. Reyna, Fuzzy Trace Theory and Medical Decisions by Minors: Differences in Reasoning between Adolescents and Adults, 38(3) J. Med. \& Phil. 268 (2013); Brian C. Partridge, The Mature Minor: Some Critical Psychological Reflections on the Empirical Bases, 38(3) J. Med. \& PHIL. 283 (2013); Rachelle Barina \& Jeffrey P. Bishop, Maturing the Minor, Marginalizing the Family: On the Social Construction of the Mature Minor, 38(3) J. Med. \& PHIL. 300 (20I3). 
decisions about whether or not to have necessary medical treatment. It also has been used to protect their sexual autonomy. ${ }^{124}$

If the mature minor standard for medical decision making is questionable in the context of genuine harm prevention oriented medical decision making, a fortiori it is questionable for nontherapeutic (harmful) cosmetic surgery decision making. An additional and related constraint is vulnerability: The bottom line is that children belong to a vulnerable class in our society and thus should not be put in a position where they have to make a decision about whether or not to have unnecessary nontherapeutic cosmetic surgery that is likely to result in long-term harmful consequences. In the U.S. Supreme Court decision in Roper v. Simmons, ${ }^{125}$ Kennedy, J., cited science and social science reports that supported his conclusion that "juveniles are more vulnerable or susceptible to negative influences and outside pressures, including peer pressure." 126 The problem has been exacerbated by the cosmetic surgery industry, whose advertizing targets people who have certain insecurities by showing before and after images and by presenting the after images as normal. ${ }^{127}$

Nonetheless, it has not been my aim to make a case for abandoning the mature minor test altogether. That is a more general debate that goes

I24. Gillick v. West Norfolk and Wisbech AHA [1986] A.C. II2. Some academics have questioned its sufficiency as a basis for justifying sexual choices made by minors. See Jennifer A. Drobac \& Leslie A. Hulvershorn, The Neurobiology of Decision Making in High Risk Youth \& the Law of Consent to Sex, I7(3) New CRIM. L. ReV. 502-5I (20I4).

I25. (2005) I25 S.Ct. II83 at II95.

I26. See also Kenneth R. Ginsburg et al., Adolescents' Perceptions of Factors Affecting Their Decisions to Seek Health Care, 273(24) J. Am. Med. Ass'N I9I3 (1995).

I27. Franklin G. Miller et al., Cosmetic Surgery and the Internal Morality of Medicine, 9(3) Cambridge Q. Healthcare Ethics 353 at 362 (2000), where it is observed: "The more extreme ads for cosmetic surgery convey the message that the models shown in the ads represent the standard of beauty to which all sensible people should aspire, and that these models have achieved that standard of beauty precisely because they have themselves submitted to cosmetic surgery (perhaps numerous times). By promoting disease and thus stimulating demand for cosmetic surgery, such advertisements clearly violate the internal morality of medicine." Analogously, see the discussion in Tennessee Secondary School Athletic Ass'n v. Brentwood Academy (2012) I27 S.Ct. 2489 at 2495, where it was said: "In too many cases, the invitation will come accompanied with a suggestion, subtle or otherwise, that failure to accept will hurt the student's chances to play high school sports and diminish the odds that she could continue on to college... Such a potent entreaty, playing as it does on youthful hopes and fears, could well exert the kind of undue pressure that 'disserve[s] the individual and societal interest' ... 'in facilitating informed and reliable decision making."' 
beyond the scope of this article. The argument presented here is simply that the mature minor test should not apply to decisions that result in the (minor) consenter risking unnecessary harm.

For example, it was noted above that in the United Kingdom some sexual offenses are designed to protect minors from being sexually exploited by schoolteachers who occupy a position of trust. To the extent that it is an offense for a schoolteacher to have sexual intercourse with her I7-year-old pupil, it is hard to justify the limitation placed on the consenter's right to consent under the harm principle. It is hard to see how a person aged I7 is harmed by having a sexual affair with a 22-year-old schoolteacher, if she is not harmed by having a sexual affair with a 22-year-old who is not her schoolteacher.

Limiting consent as a defense in such cases seems to be aimed at preventing exploitation and at protecting children from having to choose whether or not to accept the sexual advances of their teachers in the context of attending school. However, in this context it is difficult to see why the mature minor could not give a valid consent. Arguably, the law rests on a public interest justification that this is not a decision that a minor should have to make in the school context, because the minor belongs to a vulnerable class of citizens. Similarly, there is a public interest in having laws to prevent minors having to choose whether to have unnecessary cosmetic surgery to comply with socially constructed beauty norms, because that is a decision they should not have to make until they reach adulthood.

Compare the above scenario with one where the I7-year-old consents to having harmful cosmetic surgery that leaves her suffering permanent pain and injury. ${ }^{128}$ There seems to be no reason not to let a mature minor have

I28. In R. v. Cornwall [2013] I Cr. App. R. (S.) I59 at I64, a schoolteacher was given a prison sentence of sixteen months for sending messages via the Internet to pupils suggesting sexual activity, but no sexual activity took place. It was observed that had the teacher sent messages, or even had sexual relations, with the I6-year-old and I7-year-old who he tried to entice, it would have been lawful if not in the context of a relationship of trust, in other words, if he had not been their teacher. In R. v. Wilson [2008] i Cr. App. R. (S.) 543 at 544, a trainee teacher had a consensual affair with a I7-year-old girl and was jailed. Lady Justice Hallett said: "A very considerable penalty had been paid by Wilson for his behavior. His career in teaching was over and he would remain on the sexual offenders register for years to come and would never work with children again." $C f$. Belinda Carpenter et al., Harm, Responsibility, Age, and Consent, i7(I) New. Crim. L. Rev. 23 (20I4). 
a say in cases where the decision involves an activity that is aimed at harm prevention rather than an activity that unnecessarily exposes her to a risk of permanent injury. A mature minor might want to make a decision that will prevent her from being harmed, such as choosing to purchase prophylactics or contraceptives to prevent her from contracting a sexually transmitted disease or from the social burden of having a child before she is sufficiently mature to provide for it. Similarly, a decision to have necessary life-saving medical treatment or medical treatment that is aimed at preventing some greater harm by curing a genuine medical condition is a decision that relates to harm prevention, not to risking harm for a nontherapeutic or other social need. It is not objectionable to allow a mature minor to have some input in harm prevention decisions. If a mature minor refuses lifesaving treatment, then we are back in the territory of the minor choosing harm rather than harm prevention, but the courts are likely to hold that the minor is not mature.

The minor's ability to consent aside, the overriding factor is the harm principle. Regardless of whether the minor consents or whether her parents consent, what an adult person can consent to have done to her is limited by the doctrine of limited consent laid down in $R . v$. Brown. ${ }^{129}$ As we have seen, the doctrine of limited consent holds that consent is no defense in cases where the defendant inflicts actual or serious bodily harm upon the victim without lawful justification. Children can consent on their own behalf in certain limited circumstances, but neither an adult nor a child can consent to being physically harmed unless the authorized harm comes within one of the exceptions set out in $R . v$. Brown.

\section{B. Law Reform: The Minimum Should be an Offense to Protect Minors}

In Queensland, Parliament amended the Public Health Act 2005 to criminalize nontherapeutic surgery performed on minors. We need similar legislation that aims to protect minors. In Queensland, $\S 2 \mathrm{I} 3 \mathrm{~B}$ of the Pubic Health Act 2005 provides:

(I) A person must not perform, or offer to perform, a cosmetic procedure on [a child under I8 years of age]. The maximum penalty is 2 years imprisonment. 
(2) A person does not commit an offense against subsection (I) if the person believes, on grounds that are reasonable in the circumstances, that performance of the procedure is in the best interests of the child.

(3) Proof that the person did not have sufficient regard to any of the following matters is sufficient proof that the person did not have the belief mentioned in subsection (2) -

(a) if the child is able to form and express views - the views of the child, including the reasons why the child wants the procedure to be performed, taking into account the child's maturity and understanding of the procedure, including the risks, limitations and possible consequences of the procedure;

(b) to the extent it is practicable for the person to consult a parent of the child - the views of the parent, including whether the parent supports the procedure being performed on the child;

(c) the child's physical health, including whether performance of the procedure would correct a growth or congenital abnormality or the physical effect of a medical condition, illness or trauma;

(d) the child's psychological health, including whether the effect of performing the procedure on the child is likely to be positive;

(e) the timing of the procedure, including whether waiting until the child is an adult would be better than performing the procedure now.

The main problem with the Queensland offense is the potential scope of its "best interests" defense. If the surgeon can establish that she had a reasonable belief that it was in the minor's best interests to have the surgery, she will have a defense. It is not clear whether the legislation allows the "best interests" defense to apply only to genuine medical procedures that are necessary to "correct a growth or congenital abnormality or the physical effect of a medical condition, illness or trauma," but also to unnecessary harmful cosmetic surgery, which the surgeon reasonably believes is necessary for "the child's psychological health." If all the subsections (i.e., $\S \S$ $\left.{ }_{213} \mathrm{~B}(3)(a)-(e)\right)$ have to be satisfied, then the defense is limited to cases where the surgeon reasonably believes the surgery is necessary to correct a growth or congenital abnormality or to treat some other genuine medical condition.

If the defense also allows the surgeon to perform cosmetic surgery that is unnecessary to correct a genuine physical deformity, merely because she reasonably believes that the consenting child understood the risks involved, 
that the parents approved the surgery, and that the "the child's psychological health, including whether the effect of performing the procedure on the child is likely to be positive," made it in the child's best interest to have the surgery, the defense would be too wide.

Such a prong in an offense criminalizing surgery for minors has the potential to make the offense self-defeating. For example, if a I4-yearold requests breast implants or labiaplasty because she feels insecure and it would make her feel better to have one of these procedures, a surgeon relying on parental consent might use the "best interests" defense to try to medically defend unnecessary cosmetic surgery to treat a problem that requires a psychological remedy and nothing more. ${ }^{130}$ It has been reported that 250 girls under 16 have been given breast augmentations on the National Health Service in Britain, with the youngest recipient being merely Io years old. ${ }^{131}$ The justification that is invoked to disguise nontherapeutic cosmetic breast augmentations as medically necessary is the claim that it meets the putative patient's psychological needs.

I3o. Kazuhiro Hayashi et al., Importance of a Psychiatric Approach in Cosmetic Surgery, 27(4) Aesthetic Surgery J. 396 (2007). See Schulman v. Group Health Inc. (2008) II Misc. 3d 90 at 95, where McCooe, J., said: "Embarrassment is insufficient to establish medical necessity. The complaint should be dismissed upon the ground that the plaintiff failed to prove a psychological condition caused by his enlarged breasts which constituted a medical necessity to justify the surgical procedure. It is undisputed that he never saw a psychiatrist, psychologist or any medical professional including his pediatrician for a psychological problem related to his enlarged breasts." In Viveros v. State Dept. of Health and Welfare (1995) 889 P.2d IIO4 at IIO7, McDevitt, C.J., said: "The Department excludes from Medicaid coverage '[c] osmetic surgery which is not medically necessary.' Neither the federal nor Idaho's statutes and regulations define the term 'medical necessity,' but the Department has created a guideline to define the term as used in IDAPA. The Department considers a surgery to be medically necessary, and not cosmetic, if there is a stabilization or improvement in the functioning of a body part, or if the procedure relieves pain. Under this standard, emotional, mental, or psychological factors are not recognized by the Department as improvements in functioning that would be reimbursable under the Medicaid Program. ... The Department's decision to deny Medicaid is supported by the record. Nothing in the record indicates that the otoplasty surgery was medically necessary. Viveros' mother stated that the purpose of the otoplasty surgery was for psychological reasons, i.e., to improve Viveros' self-esteem and social skills." (Emphasis added.) See also A.M.L. v. Department of Health, Div. of Health Care Financing (1993) 863 P.2d 44.

I3I. Daniel Martin, 250 girls under 16 given bigger breasts on NHS at cost of $£ 5,000$ a time, (The London Daily Mail, Sept. 15, 20I2). 
Clearly, we need a law to protect minors both from parental consent and from unscrupulous doctors who are motivated by money, not medicine. The right of a parent to have his or her child have nontherapeutic harmful cosmetic surgery, whether for religious reasons or aesthetic reasons, is outweighed by the rights of the child. The state has a duty to act in a child's best interests, and this often involves protecting the child from the bad decisions of his or her parents. ${ }^{132}$

There may be cases where surgery is required as a matter of necessity, because psychological and psychiatric treatment alone does not provide a sufficient remedy, but such cases are likely to be extremely rare. Such an example is that of a limb being removed as a matter of necessity to prevent a person suffering Body Integrity Identity Disorder (BIID) from risking graver harm by trying to amputate it herself by lying her hand or arm on a railway line. ${ }^{133}$ Extreme cases of necessity should not be used by surgeons to justify their performing cosmetic surgery (i.e., breast implants, labiaplasty, etc.) on minors because psychiatric and psychological counseling provide an adequate remedy in the latter scenario. Coupled with this, in the latter scenario, there is little risk in the standard case of the minor who is denied cosmetic surgery engaging in self-harm.

\section{CONCLUSION}

It has been argued that unnecessary cosmetic surgery that carries a high risk of long-term harm should be criminalized because it involves wrongful harm. It is harmful when there is a high probability of it resulting in seriously harmful complications. In some cases the harm can occur for years after the medical procedure is performed. It is wrongful because the surgeon knows the medical science, knows the high rate of complications, knows that it is unnecessary, knows that it carries a high risk of serious harm, and knows that it is nontherapeutic, but willingly inflicts the harm for the purpose of making money. The surgeon violates the dignity of both adult and minor patients when she carries out risky nontherapeutic

I32. Landgericht (Koln) (I5I Ns I69/II) Unreported May 7, 2012 (Germany).

I33. See the cases discussed in Sarah Ramsay, Controversy Over U.K. Surgeon Who Amputated Healthy Limbs, 355(9202) The Lancet 476 (2000). 
harmful cosmetic surgery merely because a vulnerable patient has requested it.

Nontherapeutic cosmetic surgery can be harmful in a direct sense because it causes physical harm, or in an indirect sense because it reinforces artificial celebrity or racist ${ }^{134}$ appearances as the preferred social norm. In the case of children, it may be the parent pushing his or her child to conform to these absurd beauty standards. It seems that harmful cosmetic surgery has evaded criminalization because the medical profession has legitimatized it by tradition and convention. Police and prosecutors are trained to go after conduct that has traditionally been labeled as criminal and often miss the criminality in conduct that exists under a social disguise. ${ }^{135}$ The medical profession has hidden the criminal harm in unnecessary cosmetic surgery by dressing it up as genuine medicine.

Science has a major role to play in criminalization decisions. In the case at hand, scientific medical evidence is important for establishing that the particular cosmetic procedure carries an unacceptable risk of seriously harming the putative patient. A book-length evaluation of the relevant science would be necessary to draw a firm conclusion about the physical harmfulness of a given medical procedure because it is necessary to consider not only the degree of harm involved but also the probability of the resultant harm. A further example of the relevance of science relates to the mature minor test where the science is still in dispute. Coupled with this, psychological scientific evidence is also relevant because if it can be shown that psychological counseling provides an adequate remedy, then this would show that the proposed cosmetic surgery is not necessary to make the putative patient feel psychologically content.

I34. We saw above that some Asian parents have forced their children to have eye surgery to look more Anglo. For generations, Jewish mothers have forced their daughters to have cosmetic rhinoplasties to give them a more Anglo-type nose shape. See Rita Rubin, A Nose Dive for Nose Jobs: As Standards of Beauty Shift, Rhinoplasty—Once a Rite of Passage for Jewish Teens—Declines in Popularity, (TABLET, June 7, 20I2), http://www.tabletmag.com/jewishlife-and-religion/IoI732/a-nose-dive-for-nose-jobs. See also Sander L. Gilman, Making the Body Beautiful: A Cultural History of Aesthetic Surgery (i999).

135. Dennis J. Baker \& Lucy X. Zhao, The Criminality of Fines Imposed by Car Park Companies, i76 Crim. L. \& Just. Whly. 297 (20I2); Jeffrey Reiman, The Rich Get Richer and the Poor Get Prison: Ideology, Class, and Criminal Justice (6th ed. 2000). 
Furthermore, strong evidence demonstrating the psychological benefit from cosmetic surgery would help to demonstrate that reasonably safe forms of cosmetic surgery ought not be criminalized. The psychological benefit could be sufficient to justify the patient taking a high risk of being harmed in a trivial way by the cosmetic surgery. The science might also demonstrate that the patient falls into the category of medical necessity because without the surgery she or he will suffer serious psychological harm, but such cases are likely to be extremely rare and the evidence would have to be very convincing to stop psychological harm being used as a floodgate for decriminalization of harmful cosmetic surgery.

A moral philosopher can make a moral argument for criminalization by working from the presumption that minors have less capacity than adults, but a lawmaker has to make sure that such a presumption is supported by the relevant science. Again, a book-length evaluation of the relevant science would be necessary to draw a firm conclusion about the degree of mental capacity possessed by a mature minor, but the scientific evidence as reviewed by the United States Supreme Court and by the numerous scholars cited above seems sufficient for tentatively arguing for a blanket ban against harmful cosmetic surgery for minors. The evidence seems to show that the majority of those under the age of $\mathrm{I} 8$ have less capacity than the majority of those above that age. The law has to draw a line based on the percentage of people within that population who lack full capacity.

Furthermore, psychological and scientific evidence might be used to prove that mature minors, even if mentally mature, are more vulnerable than adults. ${ }^{136}$ This would support the case for enacting a law similar to the Queensland law, because it would support the argument that a minor is particularly vulnerable and thus ought not be put in a position where she can choose unnecessary plastic surgery to conform to the artificial beauty norms that have been set by our celebrity-worshiping society. Even though consent from an autonomous adult should provide a defense to unnecessary cosmetic surgery that does not carry a high risk of serious harm, it is arguable that mature minors ought not be allowed to consent to unnecessary harmful or harmless cosmetic surgery because they belong to a vulnerable class within our society. In a nutshell, adults ought to be able to 
consent to reasonably safe cosmetic surgery, but minors ought not be allowed to consent to any cosmetic surgery.

More generally, it has been argued in this article that regardless of the mature minor argument, the wrong and harm criteria support the case for criminalizing certain cosmetic procedures. Consent from an adult, let alone a minor, ought not provide a defense to surgeons who perform cosmetic surgery where that surgery is proven to be medically unnecessary and is scientifically proven to carry a high risk of resulting in unnecessary harm. 